\title{
What Makes Them Tick? Employee Motives and Firm Innovation
}

\author{
Henry Sauermann \\ College of Management, Georgia Institute of Technology, Atlanta, Georgia 30308, \\ henry.sauermann@mgt.gatech.edu \\ Wesley M. Cohen \\ Fuqua School of Business, Duke University, Durham, North Carolina 27708; and \\ National Bureau of Economic Research, Cambridge, Massachusetts 02138, wcohen@duke.edu
}

\begin{abstract}
F conomists studying innovation and technological change have made significant progress toward under-

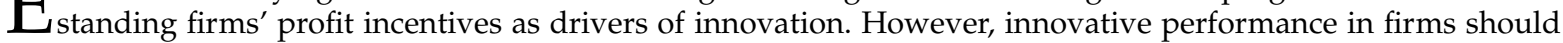
also depend heavily on the pecuniary and nonpecuniary motives of the employees actually working in research and development. Using data on more than 1,700 Ph.D. scientists and engineers, we examine the relationships between individuals' motives (e.g., desire for intellectual challenge, income, or responsibility) and their innovative performance. We find that motives matter, but different motives have very different effects: Motives regarding intellectual challenge, independence, and money have a strong positive relationship with innovative output, whereas motives regarding job security and responsibility tend to have a negative relationship. We also explore possible mechanisms underlying the observed relationships between motives and performance. Although hours worked (quantity of effort) have a strong positive effect on performance, motives appear to affect innovative performance primarily via other dimensions of effort (character of effort). Finally, we find some evidence that the role of motives differs in upstream research versus downstream development.
\end{abstract}

Key words: research and development; innovation; motivation; motives; incentives; creativity

History: Received August 7, 2009; accepted July 25, 2010, by Lee Fleming, entrepreneurship and innovation.

Published online in Articles in Advance October 25, 2010.

\section{Introduction}

Dating from the 1950s and early 1960s, economists such as Schmookler (1962), Griliches (1957), Nelson (1959), and Arrow (1962) have argued that the rate and direction of technological change could be understood as the outcome of firms' rational, profit-driven investment in innovation. In making the case for the primacy of profit as a driving force behind technical change, economists sensibly focused scholars' attention on firms and their profit incentives because firms are indeed responsible for both a good deal of innovation and particularly its commercialization. In doing so, they subordinated consideration of the impact of individuals and their motives on technical advance.

In this paper, we depart from this tradition in three ways. First, we suggest that analyses of innovation can be improved upon by paying attention to the individuals who are engaged in innovative activities within firms. Second, with the individual as the unit of analysis, we move away from an exclusive concern with pecuniary incentives to consider nonpecuniary factors. In this regard, we build upon a psychologically grounded approach to the study of innovation and reprise some of the themes articulated long ago by Schumpeter $(1934,1942)$ and other scholars of technical change. Third, we suggest that it is important to consider not only incentives, i.e., contingent benefits provided by the firm, but also researchers' motives, i.e., their preferences for such incentives. While economists focus on incentives, the role of motives has remained largely unexplored.

Our work complements other streams of literature that suggest a potential role for nonpecuniary factors in innovation. For example, a long stream of research has documented that inventors are characterized by pecuniary as well as nonpecuniary motives, and the research and development (R\&D) management literature suggests a variety of nonfinancial tools to motivate R\&D personnel (Gambardella et al. 2006, Katz 2004, MacKinnon 1962, Manners et al. 1997, Pelz and Andrews 1976). Perhaps most interestingly, some programmers in the open source movement appear to give away creative output "for free," although it is not clear what exactly the underlying motives are and whether any nonpecuniary motives observed in open source also matter in R\&D more generally (Lakhani and von Hippel 2003, Lerner and Tirole 2005, Roberts et al. 2006). And, of course, the sociology and economics of science literatures have long emphasized the importance of nonpecuniary motives 
among academic scientists (Dasgupta and David 1994, Merton 1973, Stephan 1996, Stern 2004). ${ }^{1}$

Although these literatures suggest an important role for individual-level motives, there is a dearth of large-sample empirical research examining whether and how individual motives-especially those that are nonpecuniary - are related to innovative activities and performance in firms. We begin to address this gap. Using two waves of National Science Foundation (NSF) survey data from more than 1,700 Ph.D. scientists and engineers engaged in $R \& D$ in a range of manufacturing and service sector industries, we examine the relationships between individuals' motives, such as desire for income and intellectual challenge, and innovative performance. We also examine whether different motives have different effects on performance, which mechanisms link motives and performance, and whether the effects of motives differ between upstream research and downstream development activities.

Our findings suggest that motives matter, that different motives can have different effects, and that the effects of motives may differ across tasks. In brief, we find strong and robust positive relationships between individuals' desires for income, independence, and especially intellectual challenge on the one hand, and the number of individuals' U.S. patent applications on the other. Surprisingly, we find no evidence that the quantity of effort (hours worked), though an important predictor of output, mediates the relationship between motives and output. This, in turn, suggests that the observed effects of motives on output operate through other dimensions of effort, i.e., through the "character of effort" rather than its quantity.

By establishing robust relationships between individual motives and innovative performance in a broad sample of industrial scientists and engineers, our results suggest that, in addition to considering firm-level profit incentives, future theoretical and empirical work on firm innovation may benefit from a more explicit consideration of individuals' motives. Moreover, consistent with Stern's (2004) findings, scholars might expand their purview to consider nonpecuniary as well as pecuniary motives and incentives.

\section{Relationships Between Individuals' Motives and Inventive Performance}

\subsection{Motives}

Our premise is that an individual's motivation to perform an activity depends upon the expected benefits

\footnotetext{
${ }^{1}$ Although typically not concerned with innovation per se, economic theorists have also recently begun to consider agents' nonpecuniary motives (Akerlof and Kranton 2005, Besley and Ghatak 2005, Lacetera and Zirulia 2008, Murdock 2002).
}

from engaging in that activity (e.g., contingent pay) as well as upon the intensity of her preferences for these benefits (e.g., how much does she care about money). We refer to benefits that are contingent upon individuals' effort or performance as incentives. We refer to individuals' preferences for such work benefits as motives. ${ }^{2}$ Our focus in this paper is on individuals' motives and their relationships with innovative output.

Prior work on employee motivation has highlighted a wide range of motives, including desires for income, intellectual challenge, career advancement, recognition, improving social welfare, or the desire for control and responsibility. Although many of these motives are likely to be important to employees generally, prior work on scientists specifically has focused on a smaller set of motives, including the desire for intellectually challenging work, for money, and for recognition (cf. Cohen and Sauermann 2007, Giuri et al. 2007, Katz 2004, Sauermann et al. 2010, Schumpeter 1942, Stephan and Levin 1992).

In an effort to systematize motivational factors, the psychology literature distinguishes between intrinsic and extrinsic motivation (Amabile 1996, Ryan and Deci 2000), which can be extended to distinguish between intrinsic and extrinsic motives. Individuals are extrinsically motivated if they seek to obtain benefits that are provided by some environmental entity such as a market, a superior, or a body of peers upon an evaluation of effort or performance. Extrinsic benefits do not result directly from engaging in the task, but are separable and indirect task outcomes. Extrinsic benefits are those often considered by economists, and within this class of benefits, economists typically focus on pecuniary benefits such as pay. In contrast, individuals are intrinsically motivated if they seek to obtain benefits that originate from within the individual or the activity itself-not the environment-and often reflect an interaction between particular characteristics of the activity (e.g., particular problem area) and of the individual (e.g., interest in that problem area). ${ }^{3}$ Intrinsic motivation is supported by autonomy in choosing tasks and approaches. Individuals have a fundamental need for autonomy per se, but it also

\footnotetext{
${ }^{2}$ The concept of "motives" refers to individuals' trait-like preferences and should be distinguished from "motivation," which is a state in reference to a particular task and may be interpreted as reflecting the interaction of individuals' motives and the incentives tied to the task (cf. Van Eerde and Thierry 1996). Although the social psychology literature sometimes discusses motives per se (cf. Ambrose and Kulik 1999), the focus is on levels of motivation and on distinguishing different types of motivation.

${ }^{3}$ This implies that intrinsic benefits, unlike extrinsic benefits such as money, are subjective and do not exist independently from a reference individual. A given work attribute may provide an intrinsic benefit in the eyes of one employee but not another.
} 
allows individuals to select problems that are of particular interest to them and to attribute success to their own actions, all of which may increase intrinsic motivation (cf. Frey and Stutzer 2004, Gagne and Deci 2005, Hackman and Oldham 1976).

The concept of intrinsic motivation was initially proposed as a critical reaction to dominant theories that viewed behaviors as motivated solely by extrinsic rewards (e.g., Skinner 1953). Going beyond the intrinsic/extrinsic dichotomy, more recent theories propose a continuum of motivations, characterized by different degrees to which goals are internalized (Ryan and Deci 2000). We suggest below that, in addition, the consideration of different, specific intrinsic or extrinsic motives, as well as motives that do not fit neatly in either category, may be important because different motives-even those that are very similar with respect to their intrinsic/extrinsic nature-may have different effects on innovative performance.

However, why should the motives of individual scientists and engineers-as opposed to the incentives of the firm as a whole-matter at all for a firm's innovation? First, R\&D employees are able to exercise a considerable degree of autonomy (Sauermann and Stephan 2010, Vallas and Kleinman 2008) because there is typically uncertainty about how to tackle technical challenges, and the technologists themselves often have greater expertise regarding particular problems than management. Moreover, inventive or "creative" effort is hard to observe by managers and, given the uncertainty endemic to the outcomes of invention projects, even observable outcomes may not be very informative of effort expended by employees. Consequently, the opportunity for using bureaucratic control and standard economic incentives is limited, reinforcing delegation of authority to the individual employee (Ouchi 1979, Prendergast 1999). Thus, we expect that innovative performance in firms-defined as the number and value of inventions generatedmay depend heavily on the motives of their scientists and engineers.

Scholarship in economics and psychology suggest that motives can affect performance via two main channels: through the quantity of effort (i.e., the number of hours worked) and through the character of that effort (e.g., the allocation of effort to different activities or the quality of cognitive effort). To motivate our empirical analysis, we provide a brief overview of these two channels.

\subsection{Effects of Motives via Quantity of Effort}

The quantity of effort (hours worked) is typically the central decision variable in economic agency models as well as in expectancy models in social psychology (e.g., Lacetera 2009, Lazear 1997, Prendergast 1999, Van Eerde and Thierry 1996). These models often focus on the effects of contingent rewards, but also imply that the "incentive effect" of a given reward depends on the individual's preferences for such a reward, i.e., his or her motives. More specifically, stronger preferences for a particular extrinsic or intrinsic reward increase the marginal utility of a given unit of reward and will increase optimal effort. Thus, effort is a positive function of both the size of the reward (e.g., the monetary value of a bonus) and the intensity of the individual's preference for that reward (e.g., how much the individual cares about money). ${ }^{4}$

Regarding the effects of individuals' effort on output, economic models typically assume a positive relationship, which should hold for R\&D as well. Innovative activities are, however, characterized by uncertainty, which may attenuate the link between the quantity of effort and performance. Assuming that downstream development activities are characterized by a lower degree of uncertainty and are more routinized and structured than upstream research activities, we would expect that the quantity of effort is a better predictor of performance in downstream activities than in upstream research.

\subsection{Effects of Motives via Character of Effort}

In addition to affecting performance by leading individuals to work more hours, motives may also condition the character of a given quantity of effort. We use the notion of "character of effort" to reflect the idea that effort is multidimensional and that a given number of hours can be characterized by the allocation of that effort to different activities or by the intensity or quality of cognitive effort.

2.3.1. Effects via Intermediate Activities. Individuals' motives may shape intermediate activities such as project selection, information sharing, or interactions with the scientific community, which in turn may impact performance. There are many potentially mediating activities, and each may be related in different ways to individuals' motives. For example, assuming that employees influence their project assignments, a scientist's preference for intellectual challenge may drive her to select more challenging, and thus potentially more technologically significant, projects. Alternatively, someone with the desire to minimize the risk of failure may select more incremental tasks with more certain outcomes (Dunbar 1995). Interactions with the broader scientific community are another activity that may mediate the relationships between motives and output. In

\footnotetext{
${ }^{4}$ A prominent stream of research (e.g., Deci et al. 1999, Frey and Jegen 2001) suggests that pecuniary incentives may dampen intrinsic motivation and lead to a net decrease in effort ("motivation crowding-out"). Unfortunately, a discussion of this literature is beyond the scope of this paper and our measures do not allow us to examine this effect empirically.
} 
particular, it is conceivable that industrial scientists and engineers with a "taste for science" (Roach and Sauermann 2010, Stern 2004) and strong desire to obtain recognition from peers choose to engage more actively with the broader scientific community, which in turn may increase their access to external knowledge and their innovative performance (Cockburn and Henderson 1998, Fleming et al. 2007).

2.3.2. Effects via Cognitive Processes. Invention requires problem solving and creativity, which, in turn, entail complex cognitive processes (Amabile 1996, Jung-Beeman et al. 2004, Weisberg 2006). ${ }^{5}$ Prior research in psychology suggests that these cognitive processes may be shaped by individuals' motives. First, cognitive effort can vary in its intensity, which one can think of as the number of information processing steps executed per unit of time (Johnson and Payne 1985, Kahneman 1973). Individuals with stronger motives or facing stronger incentives are likely to approach a given problem with a higher intensity of cognitive effort (Camerer and Hogarth 1999), thus processing more information per unit of time.

Second, a considerable body of work in psychology suggests linkages between particular types of motives and creativity. Amabile (1996) and other psychologists argue, for example, that intrinsic motivation enhances divergent and exploratory thinking that contributes to creativity (Weisberg 2006). On the other hand, motives such as desire for security and avoidance of threats may confine individuals' attention to smaller sets of possible solutions, which may inhibit their exploration of novel ideas and, in turn, diminish creativity (cf. Amabile and Conti 1999, Friedman and Foerster 2005). There is disagreement, however, regarding the effects of extrinsic incentives and motivation. Some scholars argue that extrinsic incentives such as contingent pay may undercut creativity by dampening individuals' intrinsic motivation, or by focusing individuals' attention on more expedient, incremental approaches to solving a given problem (Amabile 1996, Ariely et al. 2009, Manso 2010). Other psychologists suggest that extrinsic incentives may enhance creativity if the rewards are tied explicitly to the novelty and creativity of the product (Eisenberger and Shanock 2003).

To the extent that creativity and cognitive effort are more important in upstream research than in downstream development, one might expect the effects of motives via cognitive processes to be stronger in the former.

\footnotetext{
${ }^{5}$ Note that "cognitive processes" are conceptually distinct from cognitive capacity, which is a function of intelligence and ability. Rather, "cognitive processes" refers to the way in which individuals, consciously or subconsciously, use their cognitive capacity.
}

Overall, our discussion suggests that individuals' motives should have significant impacts on performance. These effects may be mediated by the quantity of effort (hours worked) as well as by the character of effort (e.g., intermediate activities and cognitive processes). Different motives (e.g., money versus challenge) may have different effects on performance, and these effects may also differ across types of R\&D. We now examine these relationships empirically.

\section{Data}

Our empirical analysis is based on restricted-use data from two waves (2001 and 2003) of the Survey of Doctorate Recipients (SDR), administered by the National Science Foundation. The SDR is based on a nationally representative sample of individuals who obtained a doctoral degree in a science, engineering, or health field from a U.S. institution and lived in the United States at the time of the surveys. In 2001 and 2003, the SDR achieved response rates of approximately $80 \%{ }^{6}$

We focus on a subsample of 1,707 SDR respondents who are full-time employees of private forprofit firms active in a range of industries and who responded to both waves of the SDR. A majority of our respondents-roughly $60 \%$-work in manufacturing, with the remainder working in services, primarily R\&D services. We include only respondents whose primary work classification is either basic research $(8 \%)$, applied research $(55 \%)$, development $(27 \%)$, or design (10\%) in both 2001 and 2003.

We augmented the SDR data with additional data from two sources. First, we obtained firm identifiers from the NSF. Although we were not granted permission to match those identifiers with firm-level data, they did allow us to run our analyses with and without controls for firm fixed effects. Second, we use the rankings of $\mathrm{Ph} . \mathrm{D}$. program quality from the National Research Council (Goldberger et al. 1995) as a measure of the training and ability of our respondents.

\section{Measures and Measurement Issues}

\subsection{Measures}

Summary statistics are shown in Table 1 and correlations are shown in Table 2.

\subsubsection{Key Measures.}

Motives. Respondents rated the importance of seven work benefits in response to the following question: "When thinking about a job, how important is each of the following factors to you...?" The four-point scale was anchored by 1 (not important

\footnotetext{
${ }^{6}$ More information on the SDR can be found at http://www.nsf .gov/statistics/srvydoctoratework/.
} 
Table 1 Summary Statistics

\begin{tabular}{|c|c|c|c|c|c|c|}
\hline Variable & Measure type & Mean & SD & Min & Median & Max \\
\hline Imp. intell. challenge & 4-point & 3.75 & 0.47 & 1 & 4 & 4 \\
\hline Imp. independence & 4-point & 3.56 & 0.57 & 1 & 4 & 4 \\
\hline Imp. salary & 4-point & 3.49 & 0.53 & 1 & 3 & 4 \\
\hline Imp. advancement & 4-point & 3.42 & 0.65 & 1 & 3 & 4 \\
\hline Imp. job security & 4-point & 3.40 & 0.61 & 1 & 3 & 4 \\
\hline Imp. responsibility & 4-point & 3.35 & 0.63 & 1 & 3 & 4 \\
\hline Imp. contrib. society & 4-point & 3.25 & 0.68 & 1 & 3 & 4 \\
\hline USPAPP & count & 3.66 & 8.10 & 0 & 1 & $\S$ \\
\hline USPAPP yes/no & dummy & 0.60 & 0.49 & 0 & 1 & 1 \\
\hline USPCOM & count & 0.72 & 3.66 & 0 & 0 & $\S$ \\
\hline USPCOM yes/no & dummy & 0.23 & 0.42 & 0 & 0 & 1 \\
\hline HRSWORKED & continuous & 47.06 & 6.99 & 35 & 45 & 80 \\
\hline PROFMEET & dummy & 0.73 & 0.44 & 0 & 1 & 1 \\
\hline Basic research & dummy & 0.08 & 0.27 & 0 & 0 & 1 \\
\hline Applied research & dummy & 0.55 & 0.50 & 0 & 1 & 1 \\
\hline Development & dummy & 0.27 & 0.45 & 0 & 0 & 1 \\
\hline Design & dummy & 0.10 & 0.30 & 0 & 0 & 1 \\
\hline PHD_NRC_SCORE & continuous & 3.40 & 0.76 & 0.42 & 3.43 & 4.75 \\
\hline HDTENURE & continuous & 11.73 & 8.45 & 1 & 9 & $\S$ \\
\hline JOBDEGREE & 3-point & 2.63 & 0.56 & 1 & 3 & 3 \\
\hline SALARY & continuous & 92,274 & 34,010 & $\S$ & 90,000 & $\S$ \\
\hline NEWBUS & dummy & 0.11 & 0.31 & 0 & 0 & 1 \\
\hline EMSIZE: $<10$ & dummy & 0.02 & 0.15 & 0 & 0 & 1 \\
\hline EMSIZE: $10-24$ & dummy & 0.02 & 0.15 & 0 & 0 & 1 \\
\hline EMSIZE: 25-99 & dummy & 0.07 & 0.25 & 0 & 0 & 1 \\
\hline EMSIZE: $100-499$ & dummy & 0.10 & 0.30 & 0 & 0 & 1 \\
\hline EMSIZE: 500-999 & dummy & 0.04 & 0.20 & 0 & 0 & 1 \\
\hline EMSIZE: 1000-4999 & dummy & 0.13 & 0.34 & 0 & 0 & 1 \\
\hline EMSIZE: $5000+$ & dummy & 0.62 & 0.49 & 0 & 1 & 1 \\
\hline Supervisees (SUPDIR) & count & 1.88 & 2.91 & 0 & 1 & $\S$ \\
\hline FS_DODNASA & dummy & 0.10 & 0.30 & 0 & 0 & 1 \\
\hline MALE & dummy & 0.82 & 0.39 & 0 & 1 & 1 \\
\hline USCITIZEN & dummy & 0.85 & 0.35 & 0 & 1 & 1 \\
\hline
\end{tabular}

Notes. §, Suppressed because of NSF confidentiality restrictions. Imp., importance; intell., intellectual.

at all) and 4 (very important). The seven work benefits and their associated preference measures are salary (IMP_SAL), job security (IMP_SEC), intellectual challenge (IMP_CHAL), independence (IMP_IND), opportunities for advancement (IMP_ADV), level of responsibility (IMP_RESP), and contribution to society (IMP_SOC). ${ }^{7}$ Consistent with the prior literature, we would classify the desire for salary or income as extrinsic and the desire for challenge and independence (our operationalization of autonomy) as intrinsic motives. Motives such as career advancement, achieving greater responsibility, job security, and the desire to benefit society may have intrinsic as well as extrinsic aspects. Table 1 shows that respondents rated intellectual challenge as the most important factor, followed by independence, salary, opportunities

\footnotetext{
${ }^{7}$ Although independence and job security are often considered characteristics of jobs, they can be conceptualized as rewards that are (not necessarily in a linear fashion) contingent upon individuals' effort or performance. For example, individuals who have shown high performance in the past are likely to be given more autonomy in future projects and are less likely to be laid off.
}

for advancement, job security, responsibility, and contribution to society. We examined the relationships among the preference measures using exploratory common factor analysis. Only one factor with an eigenvalue greater than 1 emerges, with loadings greater than 0.5 for the importance of challenge, independence, responsibility, and advancement. We do not combine these four measures into a factorbased index because the preference measures loading on this factor were not designed to measure the same construct, and the resulting factor score would be difficult to interpret (Pedhazur and Schmelkin 1991). Moreover, our analyses suggest that the effects of the motives loading on this factor differ significantly such that the use of a combined score would obscure important differences. We will, however, use a composite measure computed as the average of the preferences for intellectual challenge and independence (IMP_CHALIND) because these two motives are closely linked to the concept of intrinsic motivation (Gagne and Deci 2005), are highly correlated, and have very similar effects in our regression analyses. 
Table 2 Correlations

\begin{tabular}{|c|c|c|c|c|c|c|c|c|c|c|c|c|c|c|}
\hline & 1 & 2 & 3 & 4 & 5 & 6 & 7 & 8 & 9 & 10 & 11 & 12 & 13 & 14 \\
\hline 1 USPAPP & 1 & & & & & & & & & & & & & \\
\hline 2 USPCOM & $0.5916^{*}$ & 1 & & & & & & & & & & & & \\
\hline 3 HRSWORKED & $0.0901^{*}$ & 0.0331 & 1 & & & & & & & & & & & \\
\hline 4 PROFMEET & 0.0316 & -0.0004 & $0.0687^{*}$ & 1 & & & & & & & & & & \\
\hline 5 IMP_SAL & $0.0592^{*}$ & 0.0460 & $-0.0640^{*}$ & 0.0135 & 1 & & & & & & & & & \\
\hline 6 IMP_CHAL & $0.0510^{*}$ & 0.0372 & $0.1134^{*}$ & $0.0876^{*}$ & 0.0127 & 1 & & & & & & & & \\
\hline 7 IMP_IND & $0.0638^{*}$ & 0.0408 & $0.0854^{*}$ & 0.0394 & 0.0278 & $0.4553^{*}$ & 1 & & & & & & & \\
\hline 8 IMP_ADV & 0.0393 & 0.0207 & $0.0560^{*}$ & $0.0621^{*}$ & $0.2390^{*}$ & $0.2927^{*}$ & $0.1994^{*}$ & 1 & & & & & & \\
\hline 9 IMP_SOC & -0.0138 & $-0.0608 *$ & 0.0438 & $0.1111^{*}$ & 0.0102 & $0.3219^{*}$ & $0.3163^{*}$ & $0.2296^{*}$ & 1 & & & & & \\
\hline 10 IMP_SEC & -0.0119 & 0.0146 & $-0.0930^{*}$ & -0.0360 & $0.2716^{*}$ & 0.0291 & $0.0657^{*}$ & $0.1968^{*}$ & $0.1156^{*}$ & 1 & & & & \\
\hline 11 IMP_RESP & 0.0255 & 0.0214 & $0.1366^{*}$ & $0.0767^{*}$ & $0.1274^{*}$ & $0.3992^{*}$ & $0.4251^{*}$ & $0.4631^{*}$ & $0.3302^{*}$ & $0.0892^{*}$ & 1 & & & \\
\hline 12 SALARY & $0.1154^{*}$ & $0.0761^{*}$ & $0.1603^{*}$ & $0.0794 *$ & -0.0017 & $0.0622^{*}$ & $0.0627^{*}$ & $-0.0923^{*}$ & -0.0316 & $-0.1141^{*}$ & 0.0277 & 1 & & \\
\hline 13 HDTENURE & 0.0262 & $0.0519 *$ & 0.0062 & $-0.0525^{*}$ & $-0.0913^{*}$ & -0.0250 & $0.0519 *$ & $-0.2843^{*}$ & $-0.0683^{*}$ & -0.0321 & $-0.0923^{*}$ & $0.3074^{*}$ & 1 & \\
\hline 14 PHD_NRC_SCORE & 0.0406 & -0.0254 & $0.0640^{*}$ & -0.0181 & -0.0438 & $0.0576^{*}$ & -0.0160 & -0.0093 & $-0.0755^{*}$ & $-0.0522^{*}$ & -0.0379 & $0.0829 *$ & 0.0453 & 1 \\
\hline 15 LN_SUPDIR & $0.0954^{*}$ & 0.0448 & $0.1870^{*}$ & $0.1096 *$ & -0.0027 & 0.0456 & $0.0988^{*}$ & $0.0953^{*}$ & $0.0763^{*}$ & -0.0293 & $0.1344^{*}$ & $0.1501^{*}$ & 0.0340 & -0.0322 \\
\hline
\end{tabular}

*Significant at $5 \%$.

Innovative performance. Each respondent reports in 2003 the number of U.S. patent applications in which he or she was named as an inventor over the prior five years (USPAPP). The average number of U.S. patent applications is 3.66. Patent application rates are somewhat higher in basic research (4.1) and applied research (3.9) compared to development (3.2) and design (3.1). The distribution of patent applications is skewed, with $40 \%$ of the respondents having zero patents and only $30 \%$ of the respondents having more than three patent applications. A second patentrelated measure taken from the 2003 survey is the number of patents granted over the prior five years that were either licensed or resulted in a commercialized product or process (USPCOM). Whereas patent applications should reflect the quantity of inventive output more broadly, commercialized patents will reflect particularly valuable inventions. Finally, we also use self-reported annual base salary (in 2003) as a proxy for performance in a broader sense; this measure should not only capture a focal employee's own innovative performance, but also her contributions to the performance of her colleagues and to that of the organization more generally. ${ }^{8}$

Quantity of effort. The literature suggests that the quantity of effort may play a key role in mediating the relationship between motives and performance. Respondents answered the following question: "During a typical week on this job, how many hours did you usually work?" This continuous measure (HRSWORKED) has a mean of 47 hours. Note that the survey question did not limit hours worked to the physical location of the employer.

Interactions with scientific community. Respondents indicated in 2001 whether they had attended any professional society or association meetings or professional conferences in the prior year (PROFMEET;

\footnotetext{
${ }^{8}$ We thank an anonymous referee for this suggestion.
}

mean, 0.73). This measure captures an important dimension of scientists' and engineers' engagement with the broader scientific community (Cockburn and Henderson 1998, Cohen et al. 2002), which we proposed above as a potential intermediate activity.

\subsubsection{Important Controls.}

Firm identifiers. Individuals' performance is a function not only of individual-level variables but also of firm-level factors. The SDR data contain only a limited amount of information on employing firms (firm size, age, and industry; see below). However, the inclusion of firm fixed effects in our regressions allows us to control for a wide set of organizational characteristics such as resource availability, patent propensity, or organizational structure. Most importantly, firm fixed effects should also capture otherwise unobserved incentives that vary systematically across firms, e.g., whether firms pay individuals for the filing of a patent application (cf. IPO 2004).

Experience. Work experience is measured using the time since obtaining the highest degree (HDTENURE). We also have measures of respondents' age and time on the current job, which are highly correlated with HDTENURE. Using these measures instead of HDTENURE gives very similar results.

Training and ability. We matched each respondent's Ph.D.-granting institution and the Ph.D. field to the National Research Council's evaluation of Ph.D. program quality (Goldberger et al. 1995). The quality measure used is a rating of "program effectiveness in educating research scholars and scientists" (p. 31). The scale ranges from 0 ("not effective") to 5 ("extremely effective"). In addition to reflecting the quality of graduate education, this measure (PHD_NRC_SCORE) likely reflects ability more broadly to the extent that high-ability individuals self-select or are selected into high-quality Ph.D. programs. Respondents to the SDR also rated on a three-point scale the extent to which the current work 
is related to the field of the highest degree (JOBDEGREE), which we interpret as a proxy of the relevance of the Ph.D. training.

Type of $R \mathcal{E} D$. The survey asked respondents to indicate which of a list of work activities was the most important in terms of time spent. These activities included the following R\&D activities with their respective definitions: basic research, study directed toward gaining scientific knowledge primarily for its own sake; applied research, study directed toward gaining scientific knowledge to meet a recognized need; development, using knowledge gained from research for the production of materials, devices; design of equipment, processes, structures, models. For split-sample regressions, we collapse basic and applied research into one category and development and design into a second category.

Managerial status. Respondents indicated on the survey instrument the number of people they supervise directly (natural log, LN_SUPDIR). Our interviews suggest that managers may be more likely to be named as coinventors by their subordinates, potentially affecting the validity of our patent measures when this control is not included. In addition, managers may spend less time on R\&D activities.

4.1.3. Additional Measures. Table 3 briefly describes other variables and measures employed in our analyses.

\subsection{Social Desirability Bias and Common Methods Bias}

A potential concern with our data is that social desirability bias (SDB) may lead individuals to inflate ratings of motives that they think are socially desirable and to give artificially low scores to motives that may seem less socially desirable (Moorman and Podsakoff 1992). Although summary statistics regarding motives should be interpreted with that possibility in mind, more important is whether SDB could also systematically affect the correlations between motives and patent measures, and thus affect our regression results. In contrast to other surveys that ask respondents why they engage in particular activities such as patenting (e.g., Giuri et al. 2007), the SDR survey questions do not link the individuals' reports of their motives to any outcome, and it seems unlikely that respondents altered their reported motives to provide more desirable explanations for their performance. Moreover, our regressions show very different effects of motives that seem similarly "socially desirable" (e.g., contribution to society and intellectual challenge), making it unlikely that SDB is the primary driver of our results.

Another important concern is that relationships between variables may be inflated because variables are measured using a common method. For surveys
Table 3 Additional Measures

\begin{tabular}{|c|c|}
\hline Variable name & Measure description \\
\hline $\begin{array}{l}\text { Industry classification } \\
\text { (IND_NAICS) }\end{array}$ & $\begin{array}{l}\text { Dummies for } 10 \text { industries. }{ }^{\text {a }} \text { Industry } \\
\text { dummies are intended to control for } \\
\text { differences in technological opportunity } \\
\text { and other industry-level conditions } \\
\text { affecting R\&D productivity, } \\
\text { as well as for cross-industry differences } \\
\text { in patent propensities. }\end{array}$ \\
\hline $\begin{array}{l}\text { Employer firm size } \\
\text { (EMSIZE) }\end{array}$ & $\begin{array}{l}\text { Respondents were asked to estimate } \\
\text { the number of employees in their firm in } \\
\text { all locations. We represent their } \\
\text { categorical responses by a set of } \\
\text { seven dummy variables (see Table 1). }\end{array}$ \\
\hline Firm age (NEWBUS) & $\begin{array}{l}\text { Dummy }=1 \text { if firm was founded within } \\
\text { the last five years }\end{array}$ \\
\hline $\begin{array}{l}\text { Non-R\&D activities } \\
\text { (WA_NONRD) }\end{array}$ & $\begin{array}{l}\text { Respondents indicated on which } \\
\text { of a list of nine non-R\&D work } \\
\text { activities (accounting, employee relations, } \\
\text { management, production, professional } \\
\text { services, sales/marketing, quality } \\
\text { management, teaching, other) they } \\
\text { spend more than } 10 \% \text { of their time. We use } \\
\text { the number of these activities to control } \\
\text { for time spent on non-R\&D activities. }\end{array}$ \\
\hline $\begin{array}{l}\text { Field of highest degree } \\
\text { (HD_FIELD) }\end{array}$ & $\begin{array}{l}\text { Dummy coding for } 14 \text { fields } \\
\text { (biochemistry, cell/molecular biology, } \\
\text { microbiology, other biology, chemistry, } \\
\text { physics, environmental/health sciences, } \\
\text { food sciences, computer science, } \\
\text { mathematics, chemical engineering, } \\
\text { electrical engineering, other engineering, } \\
\text { other fields). }\end{array}$ \\
\hline $\begin{array}{l}\text { Classified research } \\
\text { (FS_DODNASA) }\end{array}$ & $\begin{array}{l}\text { Dummy variable indicating whether } \\
\text { the individual's work was supported } \\
\text { by a contract with/a grant from the } \\
\text { U.S. Department of Defense or the } \\
\text { NASA. Findings resulting from such } \\
\text { work may be less likely to be disclosed } \\
\text { in patents. }\end{array}$ \\
\hline Gender (MALE) & Dummy $=1$ if respondent is male \\
\hline Race & Dummies for Asian, white, and other \\
\hline U.S. citizenship & Dummy $=1$ for U.S. citizens \\
\hline Children & $\begin{array}{l}\text { Count of children under the age of } 12 \text { living } \\
\text { with the respondent. Children } \\
\text { presumably create time constraints and } \\
\text { we use this variable as control in our } \\
\text { effort regressions. }\end{array}$ \\
\hline Marital status & $\begin{array}{l}\text { Dummy }=1 \text { if married. Included as control } \\
\text { in effort regressions. }\end{array}$ \\
\hline
\end{tabular}

aThese industries include scientific R\&D services, chemicals, computers/semiconductors/electronics, pharmaceuticals, transportation equipment/ motor vehicles, computer systems design, medical equipment, materials, communications/audio/video equipment, and miscellaneous manufacturing.

such as the SDR, common methods bias may result from the use of similar scales for dependent and independent variables, implicit theories that respondents hold regarding the relationships between variables, or from priming effects of colocated questions 
(Podsakoff et al. 2003). Although all our motives were measured using the same scale, most correlations between motives are either insignificant or below 0.30 (see Table 2). No correlation exceeds 0.46 , suggesting that the measures of motives capture distinct constructs. More importantly, whereas motives were measured on four-point scales, our key dependent variables were not measured using such scales, but as counts. Common methods bias in the relationships among independent and dependent variables due to similar scales should thus be less of a concern. The "proximal separation" of key survey questions on different pages of the instrument should further limit common methods bias (Podsakoff et al. 2003).

\section{Specifications and Estimation}

\subsection{Specifications}

Our empirical analysis focuses on patent applications reported in 2003 (USPAPP2003) as the dependent variable. We first regress the patent measure on the measures of motives (reported in 2001) and on various controls to estimate the total effects of motives on performance:

USPAPP2003

$$
=f\left(\varepsilon_{i} ; \alpha+\boldsymbol{\beta M O T I V E S 2 0 0 1}_{i}+\boldsymbol{\delta C O N T R O L S}_{i}\right),
$$

where MOTIVES2001 $i$ is a vector of individual $i$ 's

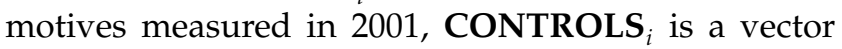
of control variables, and $\varepsilon_{i}$ is a random error term.

To examine the mechanisms underlying any observed total effects, we then include measures of potentially mediating variables, the most important one being HRSWORKED:

$$
\begin{aligned}
& {\text { USPAPP } 2003_{i}} \\
& \begin{array}{r}
=f\left(\varepsilon_{i} ; \alpha+\boldsymbol{\beta M O T I V E S 2 0 0 1 ~}_{i}\right. \\
+\gamma{\text { HRSWORKED } 2001_{i}}_{i} \\
\left.+ \text { oCONTROLS }_{i}\right) .
\end{array}
\end{aligned}
$$

We also consider attendance at professional meetings, PROFMEET, as an intermediate activity possibly mediating the effect of motives. To the extent that the quantity of effort or professional activities mediate the relationships between motives and performance, the absolute magnitude of the estimated coefficients on motives (i.e., the vector $\boldsymbol{\beta}$ ) in (2) should be reduced when compared to (1).

As discussed in more detail below, our estimates of equations such as (1) and (2) do not allow us to distinguish between the effects of motives and those of correlated unobserved incentives. Accordingly, we also estimate these models with a set of firm fixed effects to control for firm-level incentives.

To supplement our consideration of the mediating roles of HRSWORKED and PROFMEET, we also regress these measures on the measures of motives to examine to what extent motives predict the quantity of effort as well as attendance at professional meetings.

As noted above, other factors likely mediate the relationship between motives and innovative performance; unfortunately, data limitations prevent us from examining these mechanisms. For example, we have no direct measures of cognitive processes, and, arguably such processes are best explored in experimental settings. What our analysis can do, however, is eliminate possibilities; any effects of motives on performance that remain once we control for hours worked and conference attendance provide indirect evidence of the role of other intermediate activities and cognitive processes.

\subsection{Estimation Issues}

Our patent measures are counts, and given the significant degree of overdispersion, we use a negative binomial regression rather than a poisson model. Moreover, because patents are counted over five years but some respondents have fewer than five years work experience (time since graduation), we adjust the patent regressions by including the log of exposure time with the coefficient constrained to one (Long and Freese 2005).

An important limitation of the NSF's SDR data is that they do not provide explicit measures for firms' incentive systems. If motives and incentives are correlated, e.g., because of individuals' self-selection into firms with incentive systems that match their motives (Rosen 1986, Sauermann 2005), the estimated coefficients may reflect the effects of both motives and of unobserved incentives. ${ }^{9}$ To control for incentives, we also estimate key regression models with firm fixed effects for employers with two or more respondents in our sample. Assuming that fixed effects control for incentives that are provided at the level of the firm (e.g., pay for patents, but also more general norms and culture that may reflect nonpecuniary incentives), the estimated coefficients on motives in those regressions should be less affected by unobserved incentives. At the same time, including firm fixed effects may lead to a downward bias on the estimates of motives if motives differ systematically across firms. Thus, estimates without firm effects are likely to be the upper bound of the effects of motives, whereas estimates with firm fixed effects are lower bounds. Limiting our sample for the fixed effects regression to individuals in firms with at least two respondents

\footnotetext{
${ }^{9}$ Such a potential bias is of limited concern if we are interested in the effects of individuals' overall motivation on performance because overall motivation is a function of both motives and incentives (see Footnote 2).
} 
in our sample reduces our number of observations from 1,707 to 1,163. All regressions without firm fixed effects are estimated with standard errors clustered at the level of the firm.

Our ability to interpret the estimated coefficients on motives as representing causal effects hinges on the extent to which motives are exogenous. Economists routinely assume individuals' motives and preferences to be exogenous and stable, and many social psychologists consider preferences for work attributes to be "trait-like" -i.e., relatively stable over time and across contexts (cf. Amabile et al. 1994, Cable and Edwards 2004, Super 1964). It is, however, conceivable that individuals' reported preferences change in response to realized performance and benefits. For example, individuals may rationalize the receipt of little financial reward from their innovative efforts by reporting that such rewards matter little to them, or individuals may develop a stronger taste for intellectual challenge after experiencing success. To partially address this concern, we use motives measured in 2001 as predictors of outcomes reported in 2003. We also examine the stability of motives over time by comparing motives reported in 2001 with those reported in 2003 by the same individuals. We find that motives are quite stable; for example, $77 \%$ of individuals report the same importance score for challenge in 2003 as in 2001, and 66\% report the same importance score for independence. For $90 \%$ of our cases, IMP_CHALIND is either the same or has changed by no more than half a point over the two years. To assess potential endogeneity more explicitly, we regress the change in motives between 2001 and 2003 on patent output in 2001 as well as on the differences between patents reported in 2003 and 2001. We find no relationship between these performance measures and the change in motives (see Table 6, models 7 and 8 for challenge and salary motives, respectively). Overall, we conclude that endogeneity of motives is unlikely to drive our results.

\section{Results}

\subsection{Baseline Models}

The results of our baseline regressions are reported in Table 4. We regress patent applications (reported in 2003) on our set of controls in model 1, and we add the measures of motives in model 2 . The six preference measures are jointly highly significant $\left(\chi^{2}(6)=31.03, p<0.001\right)$. However, the motives have very different coefficients. First, we observe large and significant positive effects of IMP_CHALIND (our measure reflecting the importance of challenge and independence) and of the importance of salary, consistent with our expectation that these motives may increase innovative performance either via the quantity of effort or via effects on the character of effort. A one-standard-deviation (SD) higher score on the IMP_CHALIND measure (0.45 points) implies a $19 \%$ higher patent count, whereas a one-SD higher score on the importance of salary measure ( 0.53 points) implies a $15.9 \%$ higher patent count. ${ }^{10}$ The importance of responsibility has a significant negative effect, perhaps reflecting that respondents with a strong desire for responsibility are less interested in working at the bench and prefer broader organizational responsibilities, dampening their own inventive productivity. ${ }^{11}$ The importance of job security has a negative but insignificant effect; we will show below that this effect is significant in upstream research. We do not find significant effects of the motives of contributing to society or advancing one's career. ${ }^{12}$

To better understand the mechanisms underlying the observed effects of motives on patenting, we next include our measure of hours worked in the regressions (model 3). HRSWORKED has a strong positive effect, with a negative and significant quadratic term. Maximum output is predicted at a level of effort around 59 hours; the predicted number of patent applications at 59 hours of effort is $87 \%$ higher than at 40 hours. More importantly for our purposes, the inclusion of the effort measures only minimally changes the coefficients of our measures of motives.

\footnotetext{
${ }^{10} \mathrm{~A}$ positive relationship between challenge-related motives and performance does not necessarily imply a monotonic positive relationship between the objective difficulty of a task and innovative performance. Although an extensive discussion of the latter relationship is beyond the scope of this paper, we expect task difficulty to have a nonlinear effect that is also conditioned by the skills of the individual (cf. Csikszentmihalyi 1996, Siemsen 2008).

${ }^{11}$ Our regressions also include as a control the number of individuals supervised (LN_SUPDIR), which has a strong positive effect. This coefficient is consistent with our interviews suggesting that managers are often included on subordinates' patent applications. Given that the importance of responsibility has a negative coefficient even controlling for managerial status, the negative effect is unlikely to reflect distraction by managerial tasks. This is further supported by our finding below that the negative coefficient of responsibility persists if we limit the sample to nonmanagers. Although we cannot test for other potential mechanisms underlying this negative coefficient, we suspect that it may reflect an interest in broader responsibilities that do not contribute to the researchers' own innovative performance. Consistent with this interpretation, we show below that the negative effect of the responsibility motive disappears when we measure performance more broadly using salary as a proxy.

${ }^{12}$ Several of the measures of motives are correlated and the coefficients represent partial effects. When motives are entered into the regression individually (i.e., we do not control for other motives), motives related to income, independence, and challenge have strong positive effects, whereas the other preference measures have no significant effects.
} 
Table 4 Baseline Models

\begin{tabular}{|c|c|c|c|c|c|c|c|c|c|}
\hline & \multicolumn{5}{|c|}{ Full sample } & \multicolumn{3}{|c|}{ Firms with $>1$ case in sample } & \multirow{2}{*}{$\begin{array}{c}\text { uspapp }<21 \\
9 \\
\text { nbreg } \\
\text { uspapp }\end{array}$} \\
\hline & $\begin{array}{c}1 \\
\text { nbreg } \\
\text { uspapp }\end{array}$ & $\begin{array}{c}2 \\
\text { nbreg } \\
\text { uspapp }\end{array}$ & $\begin{array}{c}3 \\
\text { nbreg } \\
\text { uspapp }\end{array}$ & $\begin{array}{c}4 \\
\text { nbreg } \\
\text { uspapp }\end{array}$ & $\begin{array}{c}5 \\
\text { nbreg } \\
\text { uspapp }\end{array}$ & $\begin{array}{c}6 \\
\text { nbreg } \\
\text { uspapp }\end{array}$ & $\begin{array}{c}7 \\
\text { nbreg } \\
\text { uspapp }\end{array}$ & $\begin{array}{c}8 \\
\text { nbreg } \\
\text { uspapp }\end{array}$ & \\
\hline IMP_SAL & & $\begin{array}{c}0.280^{* *} \\
{[0.081]}\end{array}$ & $\begin{array}{c}0.282^{* *} \\
{[0.079]}\end{array}$ & $\begin{array}{c}0.288^{* *} \\
{[0.080]}\end{array}$ & $\begin{array}{c}0.289^{* *} \\
{[0.078]}\end{array}$ & $\begin{array}{c}0.338^{* *} \\
{[0.093]}\end{array}$ & $\begin{array}{c}0.180^{*} \\
{[0.089]}\end{array}$ & $\begin{array}{c}0.198^{*} \\
{[0.090]}\end{array}$ & $\begin{array}{c}0.189^{* *} \\
{[0.062]}\end{array}$ \\
\hline IMP_CHALIND & & $\begin{array}{c}0.391^{* *} \\
{[0.101]}\end{array}$ & $\begin{array}{c}0.383^{* *} \\
{[0.102]}\end{array}$ & $\begin{array}{c}0.396^{* *} \\
{[0.100]}\end{array}$ & $\begin{array}{c}0.387^{* *} \\
{[0.101]}\end{array}$ & $\begin{array}{c}0.540^{* *} \\
{[0.114]}\end{array}$ & $\begin{array}{c}0.452^{* *} \\
{[0.127]}\end{array}$ & $\begin{array}{c}0.458^{* *} \\
{[0.127]}\end{array}$ & $\begin{array}{c}0.251^{* *} \\
{[0.091]}\end{array}$ \\
\hline IMP_ADV & & $\begin{array}{c}0.059 \\
{[0.073]}\end{array}$ & $\begin{array}{c}0.068 \\
{[0.073]}\end{array}$ & $\begin{array}{c}0.058 \\
{[0.074]}\end{array}$ & $\begin{array}{c}0.067 \\
{[0.073]}\end{array}$ & $\begin{array}{c}-0.111 \\
{[0.091]}\end{array}$ & $\begin{array}{c}0.019 \\
{[0.096]}\end{array}$ & $\begin{array}{c}0.007 \\
{[0.095]}\end{array}$ & $\begin{array}{r}-0.039 \\
{[0.067]}\end{array}$ \\
\hline IMP_SOC & & $\begin{array}{r}-0.005 \\
{[0.071]}\end{array}$ & $\begin{array}{c}-0.011 \\
{[0.070]}\end{array}$ & $\begin{array}{c}-0.014 \\
{[0.072]}\end{array}$ & $\begin{array}{c}-0.018 \\
{[0.070]}\end{array}$ & $\begin{array}{c}0.014 \\
{[0.088]}\end{array}$ & $\begin{array}{c}-0.021 \\
{[0.077]}\end{array}$ & $\begin{array}{r}-0.015 \\
{[0.079]}\end{array}$ & $\begin{array}{c}-0.004 \\
{[0.050]}\end{array}$ \\
\hline IMP_RESP & & $\begin{array}{r}-0.182^{*} \\
{[0.072]}\end{array}$ & $\begin{array}{c}-0.203^{* *} \\
{[0.071]}\end{array}$ & $\begin{array}{c}-0.190^{* *} \\
{[0.072]}\end{array}$ & $\begin{array}{c}-0.209^{* *} \\
{[0.071]}\end{array}$ & $\begin{array}{r}-0.147 \\
{[0.086]}\end{array}$ & $\begin{array}{r}-0.228^{*} \\
{[0.095]}\end{array}$ & $\begin{array}{r}-0.228^{*} \\
{[0.095]}\end{array}$ & $\begin{array}{c}-0.202^{* *} \\
{[0.064]}\end{array}$ \\
\hline IMP_SEC & & $\begin{array}{c}-0.098 \\
{[0.072]}\end{array}$ & $\begin{array}{c}-0.083 \\
{[0.068]}\end{array}$ & $\begin{array}{c}-0.090 \\
{[0.072]}\end{array}$ & $\begin{array}{c}-0.077 \\
{[0.067]}\end{array}$ & $\begin{array}{c}0.033 \\
{[0.085]}\end{array}$ & $\begin{array}{c}-0.030 \\
{[0.087]}\end{array}$ & $\begin{array}{c}-0.010 \\
{[0.084]}\end{array}$ & $\begin{array}{c}0.001 \\
{[0.057]}\end{array}$ \\
\hline HRSWORKED & & & $\begin{array}{c}0.202^{* *} \\
{[0.043]}\end{array}$ & & $\begin{array}{c}0.195^{* *} \\
{[0.043]}\end{array}$ & & & $\begin{array}{c}0.162^{* *} \\
{[0.052]}\end{array}$ & $\begin{array}{c}0.069 \\
{[0.038]}\end{array}$ \\
\hline HRSWORKED_SQ & & & $\begin{array}{c}-0.002^{* *} \\
{[0.000]}\end{array}$ & & $\begin{array}{c}-0.002^{* *} \\
{[0.000]}\end{array}$ & & & $\begin{array}{c}-0.001^{* *} \\
{[0.000]}\end{array}$ & $\begin{array}{c}0.000 \\
{[0.000]}\end{array}$ \\
\hline PROFMEET & & & & $\begin{array}{c}0.212^{*} \\
{[0.102]}\end{array}$ & $\begin{array}{c}0.160 \\
{[0.102]}\end{array}$ & & & & $\begin{array}{c}0.151 \\
{[0.081]}\end{array}$ \\
\hline Firm fixed effects & & & & & & & incl. & incl. & \\
\hline $\begin{array}{l}\text { HD_FIELD } \\
\text { PHD_NRC_SCORE }\end{array}$ & $\begin{array}{c}\text { incl. } \\
0.090 \\
{[0.058]}\end{array}$ & $\begin{array}{c}\text { incl. } \\
0.076 \\
{[0.057]}\end{array}$ & $\begin{array}{c}\text { incl. } \\
0.069 \\
{[0.056]}\end{array}$ & $\begin{array}{l}\text { incl. } \\
0.081 \\
{[0.057]}\end{array}$ & $\begin{array}{c}\text { incl. } \\
0.073 \\
{[0.056]}\end{array}$ & $\begin{array}{c}\text { incl. } \\
0.060 \\
{[0.066]}\end{array}$ & $\begin{array}{c}\text { incl. } \\
0.099 \\
{[0.064]}\end{array}$ & $\begin{array}{c}\text { incl. } \\
0.098 \\
{[0.064]}\end{array}$ & $\begin{array}{l}\text { incl. } \\
0.131^{* *} \\
{[0.048]}\end{array}$ \\
\hline JOBDEGREE & $\begin{array}{c}-0.124 \\
{[0.099]}\end{array}$ & $\begin{array}{c}-0.124 \\
{[0.096]}\end{array}$ & $\begin{array}{c}-0.105 \\
{[0.094]}\end{array}$ & $\begin{array}{c}-0.137 \\
{[0.095]}\end{array}$ & $\begin{array}{c}-0.117 \\
{[0.093]}\end{array}$ & $\begin{array}{c}-0.197 \\
{[0.103]}\end{array}$ & $\begin{array}{c}0.011 \\
{[0.087]}\end{array}$ & $\begin{array}{c}0.030 \\
{[0.086]}\end{array}$ & $\begin{array}{r}-0.052 \\
{[0.070]}\end{array}$ \\
\hline HDTENURE & $\begin{array}{c}0.003 \\
{[0.022]}\end{array}$ & $\begin{array}{c}0.002 \\
{[0.021]}\end{array}$ & $\begin{array}{c}0.011 \\
{[0.021]}\end{array}$ & $\begin{array}{c}0.002 \\
{[0.021]}\end{array}$ & $\begin{array}{c}0.011 \\
{[0.020]}\end{array}$ & $\begin{array}{c}-0.028 \\
{[0.024]}\end{array}$ & $\begin{array}{c}0.026 \\
{[0.022]}\end{array}$ & $\begin{array}{c}0.035 \\
{[0.021]}\end{array}$ & $\begin{array}{c}0.029 \\
{[0.017]}\end{array}$ \\
\hline HDTENURE_SQ & $\begin{array}{c}0.000 \\
{[0.001]}\end{array}$ & $\begin{array}{c}0.000 \\
{[0.001]}\end{array}$ & $\begin{array}{c}0.000 \\
{[0.001]}\end{array}$ & $\begin{array}{c}0.000 \\
{[0.001]}\end{array}$ & $\begin{array}{c}0.000 \\
{[0.001]}\end{array}$ & $\begin{array}{c}0.001 \\
{[0.001]}\end{array}$ & $\begin{array}{c}0.000 \\
{[0.001]}\end{array}$ & $\begin{array}{c}-0.001 \\
{[0.001]}\end{array}$ & $\begin{array}{r}-0.001^{*} \\
{[0.001]}\end{array}$ \\
\hline LN_SUPDIR & $\begin{array}{c}0.297^{* *} \\
{[0.065]}\end{array}$ & $\begin{array}{c}0.308^{* *} \\
{[0.065]}\end{array}$ & $\begin{array}{c}0.273^{* *} \\
{[0.062]}\end{array}$ & $\begin{array}{l}0.301^{* *} \\
{[0.065]}\end{array}$ & $\begin{array}{c}0.268^{* *} \\
{[0.063]}\end{array}$ & $\begin{array}{c}0.382^{* *} \\
{[0.076]}\end{array}$ & $\begin{array}{c}0.347^{* *} \\
{[0.072]}\end{array}$ & $\begin{array}{c}0.305^{* *} \\
{[0.072]}\end{array}$ & $\begin{array}{c}0.262^{* *} \\
{[0.052]}\end{array}$ \\
\hline WA_NONRD & $\begin{array}{c}0.031 \\
{[0.046]}\end{array}$ & $\begin{array}{c}0.011 \\
{[0.044]}\end{array}$ & $\begin{array}{r}-0.004 \\
{[0.042]}\end{array}$ & $\begin{array}{c}0.002 \\
{[0.044]}\end{array}$ & $\begin{array}{c}-0.011 \\
{[0.042]}\end{array}$ & $\begin{array}{c}0.030 \\
{[0.056]}\end{array}$ & $\begin{array}{c}0.102^{*} \\
{[0.050]}\end{array}$ & $\begin{array}{c}0.076 \\
{[0.050]}\end{array}$ & $\begin{array}{c}-0.015 \\
{[0.035]}\end{array}$ \\
\hline FS_DODNASA & $\begin{array}{c}-0.693^{* *} \\
{[0.135]}\end{array}$ & $\begin{array}{c}-0.690^{* *} \\
{[0.131]}\end{array}$ & $\begin{array}{c}-0.640^{* *} \\
{[0.130]}\end{array}$ & $\begin{array}{c}-0.707^{* *} \\
{[0.130]}\end{array}$ & $\begin{array}{c}-0.654^{* *} \\
{[0.129]}\end{array}$ & $\begin{array}{c}-0.764^{* *} \\
{[0.188]}\end{array}$ & $\begin{array}{c}-0.399 \\
{[0.219]}\end{array}$ & $\begin{array}{c}-0.297 \\
{[0.221]}\end{array}$ & $\begin{array}{c}-0.521^{* *} \\
{[0.130]}\end{array}$ \\
\hline $\begin{array}{l}\text { Applied R. } \\
\text { Development } \\
\text { Design }\end{array}$ & $\begin{array}{l}-0.059 \\
-0.467^{*} \\
-0.640^{* *}\end{array}$ & $\begin{array}{l}-0.060 \\
-0.427^{*} \\
-0.660^{* *}\end{array}$ & $\begin{array}{c}0.004 \\
-0.385^{*} \\
-0.649^{* *}\end{array}$ & $\begin{array}{l}-0.072 \\
-0.401^{*} \\
-0.623^{* *}\end{array}$ & $\begin{array}{l}-0.008 \\
-0.368^{*} \\
-0.623^{* *}\end{array}$ & $\begin{array}{c}0.081 \\
-0.372 \\
-0.592^{*}\end{array}$ & $\begin{array}{c}0.052 \\
-0.572^{* *} \\
-0.758^{* *}\end{array}$ & $\begin{array}{c}0.122 \\
-0.529^{* *} \\
-0.684^{* *}\end{array}$ & $\begin{array}{r}0.160 \\
-0.188 \\
-0.337\end{array}$ \\
\hline $\begin{array}{l}\text { IND_NAICS } \\
\text { EMSIZE } \\
\text { NEWBUS }\end{array}$ & $\begin{array}{l}\text { incl. } \\
\text { incl. } \\
0.038\end{array}$ & $\begin{array}{l}\text { incl. } \\
\text { incl. } \\
0.006\end{array}$ & $\begin{array}{c}\text { incl. } \\
\text { incl. } \\
-0.022\end{array}$ & $\begin{array}{l}\text { incl. } \\
\text { incl. } \\
0.016\end{array}$ & $\begin{array}{c}\text { incl. } \\
\text { incl. } \\
-0.014\end{array}$ & $\begin{array}{c}\text { incl. } \\
\text { incl. } \\
-0.282\end{array}$ & & & $\begin{array}{l}\text { incl. } \\
\text { incl. } \\
0.145\end{array}$ \\
\hline $\begin{array}{l}\text { MALE } \\
\text { RACE } \\
\text { US CITIZEN }\end{array}$ & $\begin{array}{c}0.308^{*} \\
\text { incl. } \\
-0.086\end{array}$ & $\begin{array}{c}0.305^{*} \\
\text { incl. } \\
-0.042\end{array}$ & $\begin{array}{c}0.259 * \\
\text { incl. } \\
-0.047\end{array}$ & $\begin{array}{c}0.302^{*} \\
\text { incl. } \\
-0.024\end{array}$ & $\begin{array}{c}0.258^{*} \\
\text { incl. } \\
-0.033\end{array}$ & $\begin{array}{c}0.282^{*} \\
\text { incl. } \\
0.049\end{array}$ & $\begin{array}{c}0.368^{* *} \\
\text { incl. } \\
-0.317\end{array}$ & $\begin{array}{c}0.315^{* *} \\
\text { incl. } \\
-0.289\end{array}$ & $\begin{array}{c}0.170 \\
\text { incl. } \\
-0.097\end{array}$ \\
\hline $\begin{array}{l}\text { Constant } \\
\text { Observations }\end{array}$ & $\begin{array}{r}-0.827 \\
1,707\end{array}$ & $\begin{array}{c}-2.410^{* *} \\
1,707\end{array}$ & $\begin{array}{c}-8.115^{* *} \\
1,707\end{array}$ & $\begin{array}{c}-2.572^{* *} \\
1,707\end{array}$ & $\begin{array}{c}-8.034^{* *} \\
1,707\end{array}$ & $\begin{array}{c}-2.908^{* *} \\
1,163\end{array}$ & $\begin{array}{c}-2.547^{* *} \\
1,163\end{array}$ & $\begin{array}{c}-7.331^{* *} \\
1,163\end{array}$ & $\begin{array}{c}-4.335^{* *} \\
1,668\end{array}$ \\
\hline $\begin{array}{l}\text { Chi-squared } \\
\text { df }\end{array}$ & 322.62 & 362.679 & 406.367 & 384.144 & 417.631 & 343.256 & $22,030.647$ & $24,332.903$ & 390.63 \\
\hline $\begin{array}{l}\text { df } \\
\text { alpha }\end{array}$ & $\begin{array}{c}43 \\
2.112\end{array}$ & $\begin{array}{c}49 \\
2.058\end{array}$ & $\begin{array}{c}51 \\
2.004\end{array}$ & $\begin{array}{c}50 \\
2.049\end{array}$ & $\begin{array}{c}52 \\
1.998\end{array}$ & $\begin{array}{c}49 \\
1.967\end{array}$ & $\begin{array}{c}230 \\
1.26\end{array}$ & $\begin{array}{c}232 \\
1.228\end{array}$ & $\begin{array}{r}52 \\
1.55\end{array}$ \\
\hline
\end{tabular}

Notes. df, Degrees of freedom. Robust standard errors are in brackets.

$*$ Significant at $5 \%$; ${ }^{* *}$ significant at $1 \%$. 
Thus, the quantity of effort is not the primary mediator of the relationships between motives and performance even though effort itself is strongly related to performance. Of course, these results hinge on the validity of HRSWORKED as a measure of the quantity of effort, and we provide a more detailed discussion of robustness checks below. These additional analyses reinforce our conclusion that the observed effects of motives are not primarily mediated by the quantity of effort.

Next, we probe the possibility that the positive relationship between IMP_CHALIND and USPAPP reflects that individuals with strong desires for challenge and independence have a stronger "taste for science" and interact more intensively with the scientific community outside their employing organizations (one aspect of the "character" of effort), which in turn may give them access to productivity-enhancing external knowledge (Cockburn and Henderson 1998, Stern 2004). We include the variable indicating participation in professional meetings in model 4 and observe a positive coefficient; scientists and engineers who attended professional meetings in the prior year have approximately $24 \%$ higher expected patent counts, controlling for the type of $R \& D$ and other variables. However, the inclusion of this variable does not substantially change the coefficients of our measures of motives. Assuming that attendance at professional meetings is a reasonable proxy for respondents' more general involvement with the larger scientific community, this suggests that the observed effects of motives on performance are unlikely to reflect a "productivity effect" stemming from links to the broader scientific and professional communities (cf. Stern 2004). ${ }^{13}$ Unfortunately, data limitations prevent us from explicitly examining other intermediate activities as potential mediators.

As discussed earlier, self-selection may lead to a positive correlation between individuals' motives and unobserved firm-level incentives, and our coefficient estimates on motives may reflect joint effects of motives and unobserved incentives. To partially address this issue, we include firm fixed effects in our key regression models, using the subsample of individuals employed in firms with at least two employees among our respondents ( $N=1,163$ individuals). Model 6 is equivalent to model 2 but estimated using the smaller sample. The firm fixed effects are included in models 7 and 8 and should capture differences across firms with respect to incentives as well as other potentially relevant firm characteristics such

\footnotetext{
${ }^{13}$ Because conference attendance may be associated with the presentation of research results, we cannot determine the causal direction of the relationship between conference attendance and performance.
}

as resource endowments, organizational structure, or propensity to patent. In addition, firm fixed effects will also capture any systematic differences across firms in employees' motives. The firm fixed effects are jointly highly significant, indicating systematic differences in patent application counts across firms. More importantly, the inclusion of the firm fixed effects leads to a significant reduction in the coefficient on the importance of salary, which now becomes smaller than the coefficient of IMP_CHALIND $\left(\chi^{2}(1)=3.22\right.$, $p=0.07)$. This change suggests that financial incentives (or employees' income motives) may differ systematically across firms, perhaps because of explicit human resource policies related to such incentives and motives (IPO 2004). Interestingly, the coefficient on IMP_CHALIND changes little and remains large and highly significant, suggesting that much of the observed relationship between IMP_CHALIND and patent applications is unrelated to characteristics of employing firms. ${ }^{14}$ This finding highlights the need to consider individual-level factors, in particular, nonpecuniary motives, when trying to explain innovative performance in firms.

One of our most important sets of control variables includes the measures for ability and training because, if it is the most able or well trained or those with a "nose for success" who most readily embrace challenge, the estimated effect of desire for challenge may reflect the effect of ability if the latter is not considered. This concern is not initially assuaged by the regressions showing no significant effect of our measures intended to reflect experience, ability, and training. One potential explanation is that conventional measures of ability are worse predictors of performance for extremely productive scientists ("geniuses") than for "normal" scientists. To examine this possibility in more detail, we dropped from the sample a small number of individuals with extremely high patent counts ( $>20$ patent applications, $2.3 \%$ of the sample). Model 9 in Table 4 shows results for those individuals with 20 or fewer patents. The effects of motives are somewhat smaller than in the benchmark specification (model 5) but remain large and significant. The quantity of effort continues to have a highly significant effect $\left(\chi^{2}(2)=\right.$ $16.79, p<0.001)$. Most importantly, we find that individuals with degrees from higher-ranked Ph.D. programs have significantly higher numbers of patent applications. We also observe that time since graduation has a positive but diminishing relationship

\footnotetext{
${ }^{14}$ To examine the extent to which firm dummies capture systematic differences in motives (versus incentives) across firms, we regressed the measures of motives on the firm dummies. The firm dummies are jointly significant for all measures of motives, suggesting that motives differ systematically across firms. However, the firm dummies explain only a small share of the variation in motives.
} 
with patent counts $\left(\chi^{2}(2)=9.62, p<0.01\right)$. The coefficients of motives are virtually unchanged whether or not the ability controls are included. Thus, although our ability measures may not pick up the especially productive "geniuses" among our Ph.D. respondents (or conceivably those who overstate their patent production), they do control for the experience and ability for the large majority of the sample. Our confidence in the ability measures is reinforced in an exercise described below where, instead of using patents as an indicator of innovative performance, we use salary as a broader indicator of performance, controlling for a range of other factors that may affect salary. In this case, our measures of experience, ability, and training are highly significant. Most importantly, although the inclusion of these measures leads to minor changes in the coefficients of motives, these coefficients remain highly significant.

\subsection{Differences Across Types of R\&D}

Our conceptual discussion suggested potential differences in the role of motives across tasks, in particular, upstream research versus downstream development. First, we conjectured that the quantity of effort (HRSWORKED) may play a more important role as a mediating variable in development and design where work tends to be more routinized, whereas cognitive processes may play a more important role in upstream research where employees are likely to have more latitude over what they do and where creativity may be more important. Accordingly, we split the sample into respondents who were primarily engaged in basic/applied research $(N=1,074)$ and respondents who were engaged primarily in development/design $(N=633)$. Models 1 and 2 in Table 5 show key results for the two subsamples, largely consistent with our expectations. We find that HRSWORKED and HRSWORKED_SQUARED have somewhat stronger effects in development and design $\left(\chi^{2}(2)=20.21\right)$ than in applied and basic research $\left(\chi^{2}(2)=11.33\right)$; however, this difference is not statistically significant, and effort is not a significant mediator in either of the two subsamples. Interestingly, attendance at professional meetings is highly significant in the basic/applied sample, but not in development/design, suggesting that interactions with the broader scientific community and access to external knowledge may be more beneficial for upstream research than for downstream R\&D activities.

Once we control for both HRSWORKED and attendance at professional meetings, the effects of IMP_CHALIND and of the importance of salary are positive and strong in basic/applied research and are somewhat weaker in development/design. We also observe that the negative coefficient of the importance of job security is significant in basic/applied research, consistent with the idea that a concern with job security may lead individuals to pursue safer and less significant projects or that job security is linked to risk aversion that may dampen creativity. In addition, we observe that the coefficient of the importance of responsibility is somewhat larger in development and design, though the difference is again not significant. One potential interpretation is that downstream R\&D offers individuals more opportunities to take responsibilities that are not directly R\&D related (and do not result in patents), e.g., by working with marketing or service departments.

\subsection{Additional Analyses of the Role of Hours Worked}

An important concern is the possibility that HRSWORKED measures the actual quantity of effort with considerable error. For example, HRSWORKED may underestimate the true quantity of effort if, despite the questionnaire asking respondents to report all hours worked, individuals do not report the time they work outside of the office, or the time spent thinking about work-related problems while engaged in other activities. Unreported quantity of effort makes HRSWORKED a noisy indicator of the true quantity of effort, possibly attenuating relationships between HRSWORKED and other key variables. However, there is also the possibility that the share of those unreported hours is systematically larger for more motivated individuals, if, for example, unreported hours react more strongly to motives than reported hours. Assuming, however, that reported and unreported hours are correlated, the strong main effects of effort in the expected direction combined with only small changes in the coefficients of motives once HRSWORKED is included nonetheless suggests that measurement error in HRSWORKED due to unreported hours worked is not primarily responsible for the remaining effects of motives.

We conduct several robustness checks involving the HRSWORKED measure. First, we address the possibility that the effect of HRSWORKED is more complex than that captured by linear and quadratic terms by including a dummy variable for each five-hour interval. The coefficients of the dummy variables (not shown) roughly reflect the more parsimonious quadratic specification, and the inclusion of these dummies does not lead to an appreciable change in the coefficients of motives. Second, we address the possibility that the hours reported at a given point in time are a noisy measure of the hours worked over a longer period of time (despite the survey question asking for hours worked in a "typical" work week). A comparison of HRSWORKED reported in 2003 with that reported in 2001 shows a difference of no more than five hours for $79 \%$ of the respondents. Reestimating 
Table 5 Differences Across Tasks and Robustness of Hours Worked

\begin{tabular}{|c|c|c|c|c|c|c|c|}
\hline & \multirow{2}{*}{$\begin{array}{c}\text { Basic/Appl. } \\
1 \\
\text { nbreg } \\
\text { uspapp }\end{array}$} & \multirow{2}{*}{$\begin{array}{c}\text { Dev./Des. } \\
2 \\
\text { nbreg } \\
\text { uspapp }\end{array}$} & \multirow{2}{*}{$\begin{array}{c}\text { Chg. in HRS }<6 \\
3 \\
\text { nbreg } \\
\text { uspapp }\end{array}$} & \multirow{2}{*}{$\begin{array}{c}\mathrm{HRS} \neq 40 \\
4 \\
\text { nbreg } \\
\text { uspapp }\end{array}$} & \multirow{2}{*}{$\begin{array}{c}\text { Male } \\
5 \\
\text { nbreg } \\
\text { uspapp }\end{array}$} & \multicolumn{2}{|c|}{ Full sample } \\
\hline & & & & & & $\begin{array}{c}6 \\
\text { truncreg } \\
\text { hrsworked }\end{array}$ & $\begin{array}{c}7 \\
\text { probit } \\
\text { profmeet }\end{array}$ \\
\hline IMP_SAL & $\begin{array}{c}0.369^{* *} \\
{[0.091]}\end{array}$ & $\begin{array}{c}0.227^{*} \\
{[0.114]}\end{array}$ & $\begin{array}{c}0.204^{* *} \\
{[0.088]}\end{array}$ & $\begin{array}{c}0.393^{* *} \\
{[0.087]}\end{array}$ & $\begin{array}{c}0.233^{* *} \\
{[0.078]}\end{array}$ & $\begin{array}{c}-0.415 \\
{[0.406]}\end{array}$ & $\begin{array}{c}0.167^{*} \\
{[0.066]}\end{array}$ \\
\hline IMP_CHALIND & $\begin{array}{l}0.400^{* *} \\
{[0.118]}\end{array}$ & $\begin{array}{c}0.321^{*} \\
{[0.149]}\end{array}$ & $\begin{array}{c}0.338^{* *} \\
{[0.111]}\end{array}$ & $\begin{array}{c}0.448^{* *} \\
{[0.106]}\end{array}$ & $\begin{array}{c}0.384^{* *} \\
{[0.106]}\end{array}$ & & \\
\hline IMP_ADV & $\begin{array}{c}0.063 \\
{[0.089]}\end{array}$ & $\begin{array}{c}0.110 \\
{[0.113]}\end{array}$ & $\begin{array}{c}0.026 \\
{[0.082]}\end{array}$ & $\begin{array}{c}0.117 \\
{[0.080]}\end{array}$ & $\begin{array}{c}0.123 \\
{[0.078]}\end{array}$ & $\begin{array}{c}-0.013 \\
{[0.367]}\end{array}$ & $\begin{array}{c}-0.062 \\
{[0.064]}\end{array}$ \\
\hline IMP_SOC & $\begin{array}{c}0.015 \\
{[0.073]}\end{array}$ & $\begin{array}{c}-0.044 \\
{[0.092]}\end{array}$ & $\begin{array}{c}0.01 \\
{[0.068]}\end{array}$ & $\begin{array}{c}0.012 \\
{[0.081]}\end{array}$ & $\begin{array}{c}-0.009 \\
{[0.073]}\end{array}$ & $\begin{array}{c}-0.399 \\
{[0.334]}\end{array}$ & $\begin{array}{c}0.064 \\
{[0.053]}\end{array}$ \\
\hline IMP_RESP & $\begin{array}{r}-0.164^{*} \\
{[0.074]}\end{array}$ & $\begin{array}{r}-0.288^{*} \\
{[0.120]}\end{array}$ & $\begin{array}{c}-0.171^{*} \\
{[0.079]}\end{array}$ & $\begin{array}{c}-0.229 * * \\
{[0.084]}\end{array}$ & $\begin{array}{c}-0.235^{* *} \\
{[0.079]}\end{array}$ & $\begin{array}{c}1.117^{* *} \\
{[0.379]}\end{array}$ & $\begin{array}{c}0.089 \\
{[0.059]}\end{array}$ \\
\hline IMP_SEC & $\begin{array}{r}-0.172^{*} \\
{[0.086]}\end{array}$ & $\begin{array}{c}-0.047 \\
{[0.094]}\end{array}$ & $\begin{array}{c}-0.038 \\
{[0.066]}\end{array}$ & $\begin{array}{c}-0.139 \\
{[0.079]}\end{array}$ & $\begin{array}{c}-0.062 \\
{[0.081]}\end{array}$ & $\begin{array}{c}-0.501 \\
{[0.351]}\end{array}$ & $\begin{array}{c}-0.041 \\
{[0.057]}\end{array}$ \\
\hline HRSWORKED & $\begin{array}{c}0.149 * * \\
{[0.051]}\end{array}$ & $\begin{array}{c}0.241^{* *} \\
{[0.070]}\end{array}$ & $\begin{array}{c}0.311^{* *} \\
{[0.087]}\end{array}$ & $\begin{array}{c}0.132 * \\
{[0.053]}\end{array}$ & $\begin{array}{c}0.206^{* *} \\
{[0.045]}\end{array}$ & & \\
\hline HRSWORKED_SQ & $\begin{array}{c}-0.001^{* *} \\
{[0.000]}\end{array}$ & $\begin{array}{c}-0.002^{* *} \\
{[0.001]}\end{array}$ & $\begin{array}{c}-0.003^{* *} \\
{[0.001]}\end{array}$ & $\begin{array}{c}-0.001 * \\
{[0.001]}\end{array}$ & $\begin{array}{c}-0.002^{* *} \\
{[0.000]}\end{array}$ & & \\
\hline PROFMEET & $\begin{array}{c}0.435^{* *} \\
{[0.122]}\end{array}$ & $\begin{array}{c}-0.080 \\
{[0.147]}\end{array}$ & & & & & \\
\hline IMP_CHAL & & & & & & $\begin{array}{r}1.234^{*} \\
{[0.513]}\end{array}$ & $\begin{array}{c}0.051 \\
{[0.078]}\end{array}$ \\
\hline IMP_IND & & & & & & $\begin{array}{c}-0.228 \\
{[0.411]}\end{array}$ & $\begin{array}{c}-0.110 \\
{[0.074]}\end{array}$ \\
\hline $\begin{array}{l}\text { HD_FIELD } \\
\text { PHD_NRC_SCORE }\end{array}$ & $\begin{array}{c}\text { incl. } \\
0.007 \\
{[0.065]}\end{array}$ & $\begin{array}{c}\text { incl. } \\
0.171 \\
{[0.089]}\end{array}$ & $\begin{array}{c}\text { incl. } \\
0.107 \\
{[0.067]}\end{array}$ & $\begin{array}{l}\text { incl. } \\
0.070 \\
{[0.064]}\end{array}$ & $\begin{array}{c}\text { incl. } \\
0.049 \\
{[0.059]}\end{array}$ & $\begin{array}{c}\text { incl. } \\
0.256 \\
{[0.243]}\end{array}$ & $\begin{array}{c}\text { incl. } \\
0.048 \\
{[0.044]}\end{array}$ \\
\hline JOBDEGREE & $\begin{array}{c}-0.086 \\
{[0.101]}\end{array}$ & $\begin{array}{c}-0.115 \\
{[0.109]}\end{array}$ & $\begin{array}{c}-0.084 \\
{[0.095]}\end{array}$ & $\begin{array}{c}-0.078 \\
{[0.099]}\end{array}$ & $\begin{array}{c}-0.097 \\
{[0.101]}\end{array}$ & $\begin{array}{c}0.137 \\
{[0.354]}\end{array}$ & $\begin{array}{c}0.212^{* *} \\
{[0.058]}\end{array}$ \\
\hline HDTENURE & $\begin{array}{c}0.018 \\
{[0.024]}\end{array}$ & $\begin{array}{c}0.019 \\
{[0.030]}\end{array}$ & $\begin{array}{c}0.005 \\
{[0.022]}\end{array}$ & $\begin{array}{c}0.019 \\
{[0.022]}\end{array}$ & $\begin{array}{c}0.014 \\
{[0.021]}\end{array}$ & $\begin{array}{c}0.050 \\
{[0.109]}\end{array}$ & $\begin{array}{c}-0.020 \\
{[0.017]}\end{array}$ \\
\hline HDTENURE_SQ & $\begin{array}{c}0.000 \\
{[0.001]}\end{array}$ & $\begin{array}{c}-0.002 \\
{[0.001]}\end{array}$ & $\begin{array}{c}0.000 \\
{[0.001]}\end{array}$ & $\begin{array}{c}0.000 \\
{[0.001]}\end{array}$ & $\begin{array}{c}0.000 \\
{[0.001]}\end{array}$ & $\begin{array}{c}-0.001 \\
{[0.003]}\end{array}$ & $\begin{array}{c}0.000 \\
{[0.000]}\end{array}$ \\
\hline LN_SUPDIR & $\begin{array}{c}0.234^{* *} \\
{[0.072]}\end{array}$ & $\begin{array}{c}0.300^{* *} \\
{[0.093]}\end{array}$ & $\begin{array}{c}0.331^{* *} \\
{[0.069]}\end{array}$ & $\begin{array}{c}0.254^{* *} \\
{[0.073]}\end{array}$ & $\begin{array}{c}0.269^{* *} \\
{[0.066]}\end{array}$ & $\begin{array}{c}1.672^{* *} \\
{[0.278]}\end{array}$ & $\begin{array}{c}0.136^{* *} \\
{[0.050]}\end{array}$ \\
\hline WA_NONRD & $\begin{array}{c}-0.018 \\
{[0.048]}\end{array}$ & $\begin{array}{c}-0.030 \\
{[0.056]}\end{array}$ & $\begin{array}{c}-0.065 \\
{[0.045]}\end{array}$ & $\begin{array}{c}-0.016 \\
{[0.052]}\end{array}$ & $\begin{array}{c}0.000 \\
{[0.048]}\end{array}$ & $\begin{array}{c}1.067^{* *} \\
{[0.152]}\end{array}$ & $\begin{array}{l}0.137^{* *} \\
{[0.029]}\end{array}$ \\
\hline FS_DODNASA & $\begin{array}{c}-0.754^{* *} \\
{[0.178]}\end{array}$ & $\begin{array}{r}-0.485^{*} \\
{[0.202]}\end{array}$ & $\begin{array}{c}-0.664^{* *} \\
{[0.163]}\end{array}$ & $\begin{array}{c}-0.545^{* *} \\
{[0.142]}\end{array}$ & $\begin{array}{c}-0.728^{* *} \\
{[0.136]}\end{array}$ & & $\begin{array}{c}0.187 \\
{[0.125]}\end{array}$ \\
\hline $\begin{array}{l}\text { Applied R. } \\
\text { Development } \\
\text { Design }\end{array}$ & -0.036 & -0.228 & $\begin{array}{l} \\
\quad 0.126 \\
-0.22 \\
-0.456\end{array}$ & $\begin{array}{l}-0.062 \\
-0.509^{*} \\
-0.537\end{array}$ & $\begin{array}{c}0.048 \\
-0.281 \\
-0.560^{*}\end{array}$ & $\begin{array}{l}-1.103 \\
-0.755 \\
-1.631\end{array}$ & $\begin{array}{l}-0.052 \\
-0.157 \\
-0.460^{*}\end{array}$ \\
\hline $\begin{array}{l}\text { IND_NAICS } \\
\text { EMSIZE } \\
\text { NEWBUS }\end{array}$ & $\begin{array}{l}\text { incl. } \\
\text { incl. } \\
0.095\end{array}$ & $\begin{array}{c}\text { incl. } \\
\text { incl. } \\
-0.090\end{array}$ & $\begin{array}{l}\text { incl. } \\
\text { incl. } \\
0.036\end{array}$ & $\begin{array}{l}\text { incl. } \\
\text { incl. } \\
0.044\end{array}$ & $\begin{array}{l}\text { incl. } \\
\text { incl. } \\
0.039\end{array}$ & $\begin{array}{c}\text { incl. } \\
\text { incl. } \\
1.262\end{array}$ & $\begin{array}{l}\text { incl. } \\
\text { incl. } \\
0.108\end{array}$ \\
\hline $\begin{array}{l}\text { MALE } \\
\text { CHILDREN } \\
\text { MALE } \times \text { CHILDREN } \\
\text { MARRIED } \\
\text { RACE } \\
\text { US CITIZEN }\end{array}$ & $\begin{array}{c}\text { incl. } \\
-0.197\end{array}$ & $\begin{array}{l}\text { incl. } \\
0.188\end{array}$ & $\begin{array}{l}\text { incl. } \\
0.118\end{array}$ & $\begin{array}{c}\text { incl. } \\
-0.034\end{array}$ & $\begin{array}{l}\text { incl. } \\
0.063\end{array}$ & $\begin{array}{c}1.427^{* *} \\
-2.689^{* *} \\
2.510^{* *} \\
0.004 \\
\text { incl. } \\
-0.382\end{array}$ & $\begin{array}{c}\text { incl. } \\
-0.227^{*}\end{array}$ \\
\hline $\begin{array}{l}\text { Constant } \\
\text { Observations } \\
\text { Chi-squared } \\
\text { df } \\
\text { alpha }\end{array}$ & $\begin{array}{c}-7.118^{* *} \\
1,074 \\
394.886 \\
50 \\
1.793\end{array}$ & $\begin{array}{c}-8.598^{* *} \\
633 \\
200.46 \\
50 \\
1.894\end{array}$ & $\begin{array}{c}-10.668^{* *} \\
1,355 \\
327.127 \\
51 \\
1.953\end{array}$ & $\begin{array}{c}-6.806^{* *} \\
1,218 \\
363.474 \\
51 \\
1.953\end{array}$ & $\begin{array}{c}-8.316^{* *} \\
1,394 \\
361.117 \\
50 \\
1.924\end{array}$ & $\begin{array}{c}40.838^{* *} \\
1,707 \\
347.1 \\
53\end{array}$ & $\begin{array}{c}-2.123^{* *} \\
1,707 \\
209.74 \\
51\end{array}$ \\
\hline
\end{tabular}

Notes. Dev., development; Des., design; df, degrees of freedom. Robust standard errors are in brackets.

${ }^{*}$ Significant at $5 \% ;{ }^{* *}$ significant at $1 \%$. 
our key regressions using this smaller sample (Table 5, model 3), we find somewhat larger coefficients of HRSWORKED but again no mediating effect. Third, some individuals may misreport actual hours worked by defaulting to the "standard" answer of 40 hours ( $29 \%$ of our respondents reported exactly 40 hours). For those individuals, the actual quantity of effort would be measured with larger error than for the rest of the sample. Accordingly, we reestimated our key performance regressions without the cases reporting 40 hours (Table 5, model 4). Compared to the baseline model, the effect of hours is reduced (but remains significant), whereas the coefficients of motives increase. Based on this analysis, the use of the full sample appears to give a more accurate picture of the effects of effort on performance while also providing a more conservative estimate of the effects of motives controlling for hours worked. Finally, because females may underreport hours worked compared to males (Bound et al. 2001), we reestimate our key regressions using the sample of males $(N=1,394$; model 5$)$. The coefficients of HRSWORKED are virtually unchanged, and HRSWORKED has no appreciable mediating effect.

Even though HRSWORKED does not seem to mediate the relationship between motives and performance, we are interested in the relationships between motives and HRSWORKED per se (Table 5, model 6). Our analyses (estimated using truncated regression) show that the importance of intellectual challenge and that of responsibility significantly predict effort, whereas the other motive measures have no significant coefficients. The effects of motives are smaller than expected, which may explain why the coefficients of motives change only little in our performance regression when HRSWORKED is included (Baron and Kenny 1986). The positive effect of the importance of responsibility on effort combined with the negative effect of the importance of responsibility on innovative performance may reflect that individuals with a desire for responsibility work harder, but toward objectives other than their own innovative performance, consistent with our earlier discussion. ${ }^{15}$

\subsection{Robustness of Performance Measures}

We conducted several robustness checks regarding the measurement of performance. First, it is conceivable that patent applications are a less valid measure of innovative performance for managers than for nonmanagers. Managers may spend a considerable amount of time on non-R\&D tasks but may also be named on patent applications to which they have

\footnotetext{
${ }^{15}$ We also estimated regressions predicting attendance at professional meetings. Only the salary motive has a significant (small positive) coefficient (Table 5, model 7). Thus, there is no evidence that involvement in the broader scientific community is related to challenge or independence motives or to the motive to contribute to society.
}

made only relatively small direct contributions. Moreover, managers may generally face different sets of incentives than bench scientists and engineers, and our firm dummies may not capture these differences within firms. Although we control for managerial status in our baseline regressions, we reestimated our key models using only those individuals who are not significantly involved in management, defined as having no more than one direct report $(N=1,003)$. The results of these regressions (Table 6 , models 1 and 2) reinforce our main analysis. In particular, the size of the coefficient on the importance of salary is similar in size to our benchmark regression. The coefficient of IMP_CHALIND is even larger than in the benchmark. As noted earlier, the importance of responsibility has a significant negative effect even in this sample of nonmanagers, suggesting that this effect does not simply reflect "distraction" by managerial tasks. HRSWORKED also has a larger coefficient than in the benchmark, but again no appreciable mediating effect.

Second, we used the number of patents granted over a five-year span that were licensed or commercialized (USPCOM) as an alternative performance measure (Table 6, models 3 and 4). The virtue of this measure is that it provides a rough sense of economic value of patents. However, this measure has the potential limitation that strategic considerations may condition the firm's decision to commercialize an invention. Moreover, the commercialization introduces a substantial and highly variable time lag between the R\&D activity and the observed outcome. The results are similar to those using patent applications. The importance of salary as well as the IMP_CHALIND measure have significant positive coefficients. HRSWORKED has a marginally significant positive effect $\left(\chi^{2}(2)=5.51, p=0.06\right)$ but does not mediate the relationships between motives and commercialized patents. ${ }^{16}$

Finally, we consider the possibility that patentrelated measures do not capture the full spectrum of innovation-related performance (cf. Cohen et al. 2000). We suggest that salary may serve as an alternative proxy for individuals' own innovative performance, ${ }^{17}$ and salary may also better reflect an

\footnotetext{
${ }^{16}$ Gambardella et al. (2006) observe that European inventors whose patenting was motivated by money, career, and prestige tended to produce more valuable patents. Given the significant differences in sample and measures, we are cautious about comparing our results to those of Gambardella et al. (2006). Both studies, however, would suggest that certain motives are strongly associated with more valuable inventions and that pecuniary as well as nonpecuniary motives may have positive effects.

${ }^{17}$ Consistent with that notion, salary reported in 2003 and patent applications have a significant positive correlation $(0.12, p<0.01)$ and this relationship remains significant when we control for other factors in regressions.
} 
Table 6 Robustness of Performance/Alternative Performance Measures

\begin{tabular}{|c|c|c|c|c|c|c|c|c|}
\hline & \multicolumn{2}{|c|}{ Nonmanagers } & \multicolumn{4}{|c|}{ Full sample } & \multicolumn{2}{|c|}{ Full sample } \\
\hline & $\begin{array}{c}1 \\
\text { nbreg } \\
\text { uspapp }\end{array}$ & $\begin{array}{c}2 \\
\text { nbreg } \\
\text { uspapp }\end{array}$ & $\begin{array}{c}3 \\
\text { nbreg } \\
\text { uspcom }\end{array}$ & $\begin{array}{c}4 \\
\text { nbreg } \\
\text { uspcom }\end{array}$ & $\begin{array}{c}5 \\
\text { qreg } \\
\text { salary }\end{array}$ & $\begin{array}{c}6 \\
\text { qreg } \\
\text { salary }\end{array}$ & $\begin{array}{c}7 \\
\text { oprobit } \\
\text { diff_chal }\end{array}$ & $\begin{array}{c}8 \\
\text { oprobit } \\
\text { diff_sal }\end{array}$ \\
\hline IMP_SAL & $\begin{array}{l}0.276^{* *} \\
{[0.099]}\end{array}$ & $\begin{array}{c}0.267^{* *} \\
{[0.097]}\end{array}$ & $\begin{array}{r}0.276^{*} \\
{[0.127]}\end{array}$ & $\begin{array}{c}0.292^{*} \\
{[0.129]}\end{array}$ & $\begin{array}{c}3.194^{* *} \\
{[1.003]}\end{array}$ & $\begin{array}{c}3.229^{* *} \\
{[0.790]}\end{array}$ & & \\
\hline IMP_CHALIND & $\begin{array}{c}0.506^{* *} \\
{[0.121]}\end{array}$ & $\begin{array}{c}0.504^{* *} \\
{[0.116]}\end{array}$ & $\begin{array}{c}0.545^{* *} \\
{[0.159]}\end{array}$ & $\begin{array}{c}0.542^{* *} \\
{[0.159]}\end{array}$ & $\begin{array}{c}4.003^{* *} \\
{[1.347]}\end{array}$ & $\begin{array}{c}3.750^{* *} \\
{[1.062]}\end{array}$ & & \\
\hline IMP_ADV & $\begin{array}{c}0.014 \\
{[0.093]}\end{array}$ & $\begin{array}{c}0.052 \\
{[0.093]}\end{array}$ & $\begin{array}{c}0.053 \\
{[0.111]}\end{array}$ & $\begin{array}{c}0.049 \\
{[0.111]}\end{array}$ & $\begin{array}{c}-0.269 \\
{[0.953]}\end{array}$ & $\begin{array}{c}-0.549 \\
{[0.752]}\end{array}$ & & \\
\hline IMP_SOC & $\begin{array}{c}-0.012 \\
{[0.076]}\end{array}$ & $\begin{array}{c}-0.035 \\
{[0.072]}\end{array}$ & $\begin{array}{c}-0.082 \\
{[0.103]}\end{array}$ & $\begin{array}{c}-0.089 \\
{[0.108]}\end{array}$ & $\begin{array}{c}-0.305 \\
{[0.842]}\end{array}$ & $\begin{array}{c}-0.400 \\
{[0.661]}\end{array}$ & & \\
\hline IMP_RESP & $\begin{array}{c}-0.249^{* *} \\
{[0.089]}\end{array}$ & $\begin{array}{c}-0.294^{* *} \\
{[0.086]}\end{array}$ & $\begin{array}{r}-0.168 \\
{[0.138]}\end{array}$ & $\begin{array}{c}-0.187 \\
{[0.139]}\end{array}$ & $\begin{array}{c}0.556 \\
{[0.979]}\end{array}$ & $\begin{array}{c}0.519 \\
{[0.770]}\end{array}$ & & \\
\hline IMP_SEC & $\begin{array}{r}-0.181^{*} \\
{[0.091]}\end{array}$ & $\begin{array}{c}-0.136 \\
{[0.085]}\end{array}$ & $\begin{array}{c}0.145 \\
{[0.103]}\end{array}$ & $\begin{array}{c}0.152 \\
{[0.103]}\end{array}$ & $\begin{array}{c}-2.922^{* *} \\
{[0.868]}\end{array}$ & $\begin{array}{c}-2.695^{* *} \\
{[0.690]}\end{array}$ & & \\
\hline HRSWORKED & & $\begin{array}{c}0.367^{* *} \\
{[0.095]}\end{array}$ & & $\begin{array}{c}0.112 \\
{[0.061]}\end{array}$ & & $\begin{array}{c}1.896^{* *} \\
{[0.517]}\end{array}$ & & \\
\hline HRSWORKED_SQ & & $\begin{array}{c}-0.003^{* *} \\
{[0.001]}\end{array}$ & & $\begin{array}{c}-0.001 \\
{[0.001]}\end{array}$ & & $\begin{array}{c}-0.015^{* *} \\
{[0.005]}\end{array}$ & & \\
\hline PROFMEET & & $\begin{array}{c}0.151 \\
{[0.111]}\end{array}$ & & $\begin{array}{c}0.069 \\
{[0.157]}\end{array}$ & & $\begin{array}{l}4.417^{* *} \\
{[0.914]}\end{array}$ & & \\
\hline $\begin{array}{l}\text { HD_FIELD } \\
\text { PHD_NRC_SCORE }\end{array}$ & $\begin{array}{c}\text { incl. } \\
-0.026 \\
{[0.072]}\end{array}$ & $\begin{array}{c}\text { incl. } \\
-0.021 \\
{[0.068]}\end{array}$ & $\begin{array}{l}\text { incl. } \\
0.041 \\
{[0.079]}\end{array}$ & $\begin{array}{l}\text { incl. } \\
0.033 \\
{[0.078]}\end{array}$ & $\begin{array}{l}\text { incl. } \\
3.422^{* *} \\
{[0.664]}\end{array}$ & $\begin{array}{l}\text { incl. } \\
2.752^{* *} \\
{[0.532]}\end{array}$ & $\begin{array}{c}\text { incl. } \\
-0.033 \\
{[0.037]}\end{array}$ & $\begin{array}{c}\text { incl. } \\
0.017 \\
{[0.036]}\end{array}$ \\
\hline JOBDEGREE & $\begin{array}{c}-0.151 \\
{[0.101]}\end{array}$ & $\begin{array}{c}-0.128 \\
{[0.100]}\end{array}$ & $\begin{array}{c}-0.143 \\
{[0.135]}\end{array}$ & $\begin{array}{c}-0.145 \\
{[0.132]}\end{array}$ & $\begin{array}{c}2.358^{* *} \\
{[0.898]}\end{array}$ & $\begin{array}{l}1.931^{* *} \\
{[0.713]}\end{array}$ & $\begin{array}{c}0.009 \\
{[0.050]}\end{array}$ & $\begin{array}{c}-0.074 \\
{[0.046]}\end{array}$ \\
\hline HDTENURE & $\begin{array}{c}-0.026 \\
{[0.025]}\end{array}$ & $\begin{array}{r}-0.010 \\
{[0.023]}\end{array}$ & $\begin{array}{l}0.132^{* *} \\
{[0.033]}\end{array}$ & $\begin{array}{l}0.136^{* *} \\
{[0.033]}\end{array}$ & $\begin{array}{l}2.698^{* *} \\
{[0.251]}\end{array}$ & $\begin{array}{l}2.895^{* *} \\
{[0.198]}\end{array}$ & $\begin{array}{c}0.017 \\
{[0.015]}\end{array}$ & $\begin{array}{r}-0.012 \\
{[0.015]}\end{array}$ \\
\hline HDTENURE_SQ & $\begin{array}{c}0.001 \\
{[0.001]}\end{array}$ & $\begin{array}{c}0.000 \\
{[0.001]}\end{array}$ & $\begin{array}{c}-0.003^{* *} \\
{[0.001]}\end{array}$ & $\begin{array}{c}-0.003^{* *} \\
{[0.001]}\end{array}$ & $\begin{array}{c}-0.043^{* *} \\
{[0.007]}\end{array}$ & $\begin{array}{c}-0.048^{* *} \\
{[0.005]}\end{array}$ & $\begin{array}{c}0.000 \\
{[0.000]}\end{array}$ & $\begin{array}{c}0.001 \\
{[0.000]}\end{array}$ \\
\hline LN_SUPDIR & $\begin{array}{l}0.526^{* *} \\
{[0.174]}\end{array}$ & $\begin{array}{c}0.466^{* *} \\
{[0.170]}\end{array}$ & $\begin{array}{r}0.235^{*} \\
{[0.093]}\end{array}$ & $\begin{array}{c}0.214^{*} \\
{[0.095]}\end{array}$ & $\begin{array}{c}6.064^{* *} \\
{[0.709]}\end{array}$ & $\begin{array}{l}5.610^{* *} \\
{[0.566]}\end{array}$ & $\begin{array}{c}0.020 \\
{[0.042]}\end{array}$ & $\begin{array}{c}0.065 \\
{[0.039]}\end{array}$ \\
\hline WA_NONRD & $\begin{array}{c}-0.024 \\
{[0.050]}\end{array}$ & $\begin{array}{c}-0.035 \\
{[0.049]}\end{array}$ & $\begin{array}{c}0.143^{*} \\
{[0.059]}\end{array}$ & $\begin{array}{c}0.125^{*} \\
{[0.058]}\end{array}$ & $\begin{array}{c}0.506 \\
{[0.420]}\end{array}$ & $\begin{array}{c}-0.019 \\
{[0.335]}\end{array}$ & $\begin{array}{c}0.025 \\
{[0.026]}\end{array}$ & $\begin{array}{c}-0.036 \\
{[0.025]}\end{array}$ \\
\hline FS_DODNASA & $\begin{array}{c}-0.903^{* *} \\
{[0.204]}\end{array}$ & $\begin{array}{c}-0.855^{* *} \\
{[0.203]}\end{array}$ & $\begin{array}{c}-1.167^{* *} \\
{[0.265]}\end{array}$ & $\begin{array}{c}-1.160^{* *} \\
{[0.260]}\end{array}$ & $\begin{array}{c}-0.727 \\
{[1.812]}\end{array}$ & $\begin{array}{r}-1.749 \\
{[1.442]}\end{array}$ & & \\
\hline $\begin{array}{l}\text { Applied R. } \\
\text { Development } \\
\text { Design }\end{array}$ & $\begin{array}{c}0.502^{* *} \\
0.108 \\
-0.415\end{array}$ & $\begin{array}{r}0.508^{*} \\
0.119 \\
-0.429\end{array}$ & $\begin{array}{r}0.086 \\
0.055 \\
-0.354\end{array}$ & $\begin{array}{r}0.141 \\
0.118 \\
-0.317\end{array}$ & $\begin{array}{l}-1.935 \\
-2.035 \\
-1.846\end{array}$ & $\begin{array}{l}-1.121 \\
-1.048 \\
-0.045\end{array}$ & $\begin{array}{r}0.138 \\
0.200 \\
-0.014\end{array}$ & $\begin{array}{r}0.159 \\
0.083 \\
-0.143\end{array}$ \\
\hline $\begin{array}{l}\text { IND_NAICS } \\
\text { EMSIZE } \\
\text { NEWBUS }\end{array}$ & $\begin{array}{l}\text { incl. } \\
\text { incl. } \\
0.126\end{array}$ & $\begin{array}{l}\text { incl. } \\
\text { incl. } \\
0.113\end{array}$ & $\begin{array}{l}\text { incl. } \\
\text { incl. } \\
0.077\end{array}$ & $\begin{array}{l}\text { incl. } \\
\text { incl. } \\
0.012\end{array}$ & $\begin{array}{l}\text { incl. } \\
\text { incl. } \\
4.959^{*}\end{array}$ & $\begin{array}{l}\text { incl. } \\
\text { incl. } \\
3.568^{*}\end{array}$ & $\begin{array}{l}\text { incl. } \\
\text { incl. } \\
0.048\end{array}$ & $\begin{array}{c}\text { incl. } \\
\text { incl. } \\
-0.042\end{array}$ \\
\hline $\begin{array}{l}\text { MALE } \\
\text { RACE } \\
\text { US CITIZEN }\end{array}$ & $\begin{array}{c}0.296 \\
\text { incl. } \\
-0.061\end{array}$ & $\begin{array}{c}0.257 \\
\text { incl. } \\
-0.009\end{array}$ & $\begin{array}{l}0.552^{* *} \\
\text { incl. } \\
0.078\end{array}$ & $\begin{array}{l}0.510^{*} \\
\text { incl. } \\
0.083\end{array}$ & $\begin{array}{c}0.557 \\
\text { incl. } \\
-0.610\end{array}$ & $\begin{array}{c}0.532 \\
\text { incl. } \\
-1.270\end{array}$ & $\begin{array}{c}0.110 \\
\text { incl. } \\
-0.055\end{array}$ & $\begin{array}{c}-0.033 \\
\text { incl. } \\
0.000\end{array}$ \\
\hline USPAPP (2001) & & & & & & & $\begin{array}{c}0.000 \\
{[0.003]}\end{array}$ & $\begin{array}{r}-0.005 \\
{[0.004]}\end{array}$ \\
\hline Constant & $-2.576^{* *}$ & $-12.354^{* *}$ & $-7.126^{* *}$ & $-10.368^{* *}$ & $30.713^{* *}$ & -24.723 & & \\
\hline Observations & 1,003 & 1,003 & 1,707 & 1,707 & 1,707 & 1,707 & 1,707 & 1,707 \\
\hline Chi-squared & 359.014 & 378.409 & 432.103 & 466.526 & & & 44.377 & 67.568 \\
\hline $\begin{array}{l}\text { df } \\
\text { alpha }\end{array}$ & $\begin{array}{c}49 \\
1.973\end{array}$ & $\begin{array}{c}52 \\
1.886\end{array}$ & $\begin{array}{c}49 \\
3.988\end{array}$ & $\begin{array}{c}52 \\
3.947\end{array}$ & & & 43 & 43 \\
\hline
\end{tabular}

Notes. $\mathrm{df}$, Degrees of freedom. Robust standard errors are in brackets.

*Significant at $5 \%$; ** significant at $1 \%$. 
employee's contributions to the innovative performance of other employees in a research team or $R \& D$ lab. Although a detailed analysis of salary is beyond the scope of this paper, we estimated quantile regressions of salary on motives, controlling for other variables that have been found to affect salary such as race, gender, tenure in the firm, or size and age of the firm (Brown and Medoff 2003, Oaxaca and Ransom 1994, Oi and Idson 1999, Topel 1991), as well as labor market conditions (field and industry dummies). ${ }^{18}$ The results of these salary regressions (Table 6, models 5 and 6) are qualitatively similar to the results using patent measures. The salary motive and the IMP_CHALIND measure have significant positive effects on median salary. The importance of job security has a significant negative coefficient. Interestingly, whereas the desire for responsibility had a negative coefficient in the patent regressions, it now has an insignificant positive coefficient, perhaps reflecting that a desire for responsibility leads employees to reallocate effort away from innovative work toward other activities that are valued by the organization (thus diminishing their own innovative performance but not performance in a more general sense). The coefficients of motives change only little when HRSWORKED is included; HRSWORKED itself has a positive but diminishing effect on salary. With respect to control variables, we find as expected that salary is significantly lower in small firms but increases with the number of individuals supervised, with time since graduation, with the extent to which the current job is related to the highest degree, and with the quality of the degree-granting institution, which we interpret as measures of individuals' ability and skills.

\section{Discussion}

In their efforts to understand the determinants of industrial innovation, economists have sensibly focused their attention on characteristics of firms and firms' profit incentives. Firm innovation should, however, also depend on the motives of the individuals actually engaged in research and development work inside firms. In this paper, we examine empirically to what extent selected pecuniary and nonpecuniary motives are related to innovative performance. We also examine whether different motives have different effects, how the role of motives differs across tasks, and we consider some of the mechanisms that may

\footnotetext{
${ }^{18}$ Quantile regression, which estimates the conditional median rather than mean salary, is most appropriate for our purposes because the distribution of salary is skewed (cf. Hamilton 2000, Koenker and Hallock 2001).
}

underlie the observed relationships between motives and performance.

Our results suggest that researchers' motives matter for innovative performance and that different motives have different effects. We find a robust, strong positive association between individuals' patent applications and their preferences for income, intellectual challenge, and independence. The positive relationships between innovative output and these motives persist if we measure performance with the number of patents commercialized, which better reflects valuable innovations, or if we use salary as a broader measure of researchers' performance. The desire for responsibility is negatively associated with patent applications. We observe that the inclusion of firm fixed effects reduces the estimated effects of the income motive, suggesting that firms may differ systematically with respect to firm-level pecuniary incentives such as pay-for performance systems (IPO 2004). The observed relationships between performance and motives-especially the desire for intellectual challenge and independence-remain strong even controlling for firm effects. Overall, we largely eliminated a number of alternative explanations for the observed effects of motives, including firm-level incentives, as well as the ability, training, and experience of the respondents.

Analyses of potential mechanisms underlying the observed relationships suggest that the quantity of effort (hours worked) does not explain the effects of motives on performance, although the quantity of effort itself has a strong positive effect, especially in downstream R\&D. These results suggest that motives mainly affect innovative output by impacting not the quantity of effort, but its character, where the latter may reflect either cognitive processes or intermediate activities such as project selection or information sharing. Because of data limitations, we are able to consider only one such possible mediating mechanism-individuals' involvement in the larger scientific community-which has no mediating effect. Thus, our study points toward a need for future work to examine which aspects of the character of effort mediate the relationship between motives and performance.

Notwithstanding the need for further research on mediating mechanisms, our work suggests that applied economists studying innovation may benefit from greater focus on the role of the characteristics of individual scientists and engineers working in firms. Moreover, although the formal and informal incentives that individuals face should not be ignored, consideration of individuals' motives (i.e., individualspecific preferences) seems particularly important. Our results suggest an important role of especially those motives that are nonpecuniary-not just in 
special contexts such as open source software, but in innovation more generally. Although additional research on the role of individuals' motives seems extremely important, we recognize the empirical challenges associated with such work. Available micro data sets, including popular patent databases, typically provide little information on individuals and their motives. On the other hand, some publicly available data sets such as the NSF data used in this study include useful measures, and researchers may also consider creating new data using survey studies or experimental work.

Our study also offers implications for the economics of science. Whereas this literature typically focuses on academic scientists, we provide largesample evidence on science and engineering Ph.D.'s in industrial firms. And it is noteworthy that some "professional" motives such as the desire for intellectual challenge, long seen as critical to academic scientists (Merton 1973, Stephan and Levin 1992), also matter in industry. Our work extends the few empirical studies that have considered industrial scientists' nonpecuniary motives. In particular, Stern's (2004) analysis suggests that industrial scientists in the life sciences have a preference for pursuing their own research agenda and for publishing research results. We complement this work by showing that scientists' nonpecuniary motives are also strongly related to scientists' innovative output. Moreover, although industrial scientists' motives and incentives are often considered with respect to their interactions with the broader scientific community (cf. Cockburn and Henderson 1998, Henderson 1994), our results suggest that nonpecuniary motives matter for performance even controlling for such interactions.

Finally, our work complements social psychological studies of the impact of motivation on creativity. Although social psychologists tend to agree that intrinsic motivation can be conducive to creative performance, there is little empirical study establishing that relationship in nonexperimental settings, and particularly in R\&D organizations. Our results showing an association between patent applications (presumably reflecting a certain amount of creativity) and the importance of intellectual challenge and independence provide additional such evidence. In addition, there is continued debate regarding the relationship between extrinsic motivation and creative performance (cf. Ariely et al. 2009, Eisenberger and Shanock 2003, Hennessey and Amabile 1998). Most of the empirical work on this issue has focused on the effect of extrinsic incentives. Our work provides a complementary perspective by examining the effects of extrinsic motives. Our finding of a positive relationship between financial motives and innovative performance should be particularly relevant because it is based on nonexperimental data obtained in naturally occurring settings where pay is expected and where innovation is part of individuals' job responsibilities.

Both our conceptual discussion and our results suggest that while the common distinction between extrinsic and intrinsic motivation is helpful in numerous settings, for innovation it is also helpful to consider more specific motives. Different motives that fall in the same category (i.e., extrinsic or intrinsic) may play different roles in the innovative process, sometimes with qualitatively different effects. For example, the extrinsic motive to make money could lead a scientist to keep research findings secret to appropriate the pecuniary returns, whereas the extrinsic motive to gain peer recognition may lead the scientist to widely share research results (Merton 1973).

Future work might also consider in more detail the interplay between motives and organizationally provided incentives, which will require a consideration of multiple levels of analysis. In particular, motives and incentives are likely to interact both during the selection of individuals into organizations and during employment in a particular organization. While it would be interesting to separate the unique contributions of firm- versus individual-level factors to firm innovative performance, studies on the interactions between these factors may provide a more nuanced understanding as well as important managerial implications. Also, if motives are indeed as important as suggested by our results, we need a better understanding of where motives come from. At the level of the individual, researchers may consider the roles of genetic predispositions, early education, as well as socialization during professional training or during employment (cf. Allen and Katz 1992, Keller et al. 1992). With respect to systematic differences in individuals' motives across firms, researchers might consider to what extent organizations use various selection and socialization mechanisms to shape their employees' motives (cf. Gundry 1993, Roach and Sauermann 2010).

Our study has significant limitations. First, although the National Science Foundation's SDR data provide measures for a range of motives, we lack measures of a number of additional motives that may also be quite important for scientists and engineers employed in $R \& D$, including the desire to solve practical problems (as distinct from intellectual challenge), the desire for peer recognition, and the motive to contribute to the success of a team or organization. Second, we cannot definitively establish the causal relationship between motives and performance, although we found little evidence of the endogeneity of our motives measures. For example, we showed that motives are relatively stable over time, and we do not find any evidence 
of an effect of past performance on the change in motives over time. Finally, although we showed that neither the quantity of effort nor interactions with the broader scientific community mediated the relationship between motives and innovative performance, our data do not allow us to examine other aspects of the "character of effort" as mediating variables. It is likely, however, that no single empirical approach will be able to investigate all the mechanisms potentially linking individuals' motives to innovative performance because these mechanisms are extremely heterogeneous: some involve only one focal actor, whereas others involve teams and communities of researchers; some unfold over short periods of time, whereas others may play out over years; some are conscious, whereas others are not. Cognitive processes in particular may be hard to capture in survey work and may be best explored in experimental studies. Thus, future work may benefit from the deployment of complementary empirical approaches and cross-disciplinary collaboration between empirical economists, experimental economists, and psychologists.

Although this study is only a partial step toward understanding the role of individuals' motives in industrial innovation, we also see implications for management. Our findings of consistently strong positive effects of individuals' preferences for intellectual challenge and independence highlight the importance of intrinsic motivation for innovative performance. These effects were largely independent of firm fixed effects, suggesting that firms may benefit from more actively addressing individuals' nonpecuniary motives. To the extent that motives are stable individual-level traits, hiring processes may play a particularly important role in selecting employees with strong intrinsic motives. Of course, there are numerous costs and challenges associated with managing scientists' nonpecuniary motives. For example, assessing job applicants' motives is difficult and often fraught with biases (cf. Heath 1999). Also, unlike extrinsic benefits such as money, intrinsic benefits cannot always be provided directly; firms may have to manage them indirectly by providing "enabling conditions" such as task variety and autonomy. And, of course, employees' desires for challenging work and independence may at times conflict with firms' economic objectives. Future work is needed to provide more insights into how these challenges can be managed. Our results suggest, however, that the payoffs to successfully addressing individuals' intrinsic as well as extrinsic motives may be substantial.

\section{Acknowledgments}

The authors thank participants in seminars at the National Bureau of Economic Research, Harvard Business School,
London Business School, Massachusetts Institute of Technology, Rensselaer Polytechnic Institute, University of California (Los Angeles), INSEAD, the Fuqua School of Business, and the Georgia Institute of Technology, among others, for their comments. They thank especially Jim Adams, Teresa Amabile, Ashish Arora, Scott Cook, Jeff Edwards, Jon Fjeld, Nimmi Kannankutty, Ralph Katz, John Kounios, Rachel Kranton, Mike Lenox, Megan MacGarvie, Will Mitchell, Ramana Nanda, Luigi Orsenigo, Mike Roach, Scott Rockart, Paula Stephan, Scott Stern, and Marie Thursby. Departmental editor Lee Fleming, an associate editor, and anonymous reviewers also provided exceptional help in developing this work. Financial support from the Ewing Marion Kauffman Foundation is gratefully acknowledged. The use of NSF data does not imply NSF endorsement of the research methods or conclusions contained in this report.

\section{References}

Akerlof, G. A., R. E. Kranton. 2005. Identity and the economics of organizations. J. Econom. Perspect. 19(1) 9-32.

Allen, T. J., R. Katz. 1992. Age, education and the technical ladder. IEEE Trans. Engrg. Management 39(3) 237-245.

Amabile, T. 1996. Creativity in Context. Westview Press, Boulder, CO.

Amabile, T. M., R. Conti. 1999. Changes in the work environment for creativity during downsizing. Acad. Management J. 42(6) 630-640.

Amabile, T. M., K. G. Hill, B. A. Hennessey, E. M. Tighe. 1994. The work preference inventory-Assessing intrinsic and extrinsic motivational orientations. J. Personality Soc. Psych. 66(5) 950-967.

Ambrose, M. L., C. T. Kulik. 1999. Old friends, new faces: Motivation research in the 1990s. J. Management 25(3) 231-292.

Ariely, D., U. Gneezy, G. Loewenstein, N. Mazar. 2009. Large stakes and big mistakes. Rev. Econom. Stud. 76(2) 451-469.

Arrow, K. J. 1962. Economic welfare and the allocation of resources for invention. R. R. Nelson, ed. The Rate and Direction of Inventive Activity. Princeton University Press, Princeton, NJ, 609-626.

Baron, R. M., D. A. Kenny. 1986. The moderator-mediator variable distinction in social psychological research: Conceptual, strategic, and statistical considerations. J. Personality Soc. Psych. 51(6) 1173-1182.

Besley, T., M. Ghatak. 2005. Competition and incentives with motivated agents. Amer. Econom. Rev. 95(3) 616-636.

Bound, J., C. Brown, N. Mathiowetz. 2001. Measurement error in survey data. J. J. Heckman, E. E. Leamer, eds. Handbook of Econometrics, Vol. 5. Elsevier, Amsterdam.

Brown, C., J. L. Medoff. 2003. Firm age and wages. J. Labor Econom. 21(3) 677-697.

Cable, D. M., J. R. Edwards. 2004. Complementary and supplementary fit: A theoretical and empirical integration. J. Appl. Psych. 89(5) 822-834.

Camerer, C. F., R. M. Hogarth. 1999. The effects of financial incentives in experiments: A review and capital-labor-function framework. J. Risk Uncertainty 19(1-3) 7-42.

Cockburn, I. M., R. M. Henderson. 1998. Absorptive capacity, coauthoring behavior, and the organization of research in drug discovery. J. Indust. Econom. 46(2) 157-182.

Cohen, W. M., H. Sauermann. 2007. Schumpeter's prophecy and individual incentives as a driver of innovation. F. Malerba, S. Brusoni, eds. Perspectives on Innovation. Cambridge University Press, Cambridge, UK, 73-104. 
Cohen, W. M., R. R. Nelson, J. P. Walsh. 2000. Protecting their intellectual assets: Appropriability conditions and why U.S. manufacturing firms patent (or not). NBER Working Paper 7552, National Bureau of Economic Research, Cambridge, MA.

Cohen, W. M., R. R. Nelson, J. P. Walsh. 2002. Links and impacts: The influence of public research on industrial R\&D. Management Sci. 48(1) 1-23.

Csikszentmihalyi, M. 1996. Creativity: Flow and the Psychology of Discovery and Invention. HarperCollins, New York.

Dasgupta, P., P. A. David. 1994. Toward a new economics of science. Res. Policy 23(5) 487-521.

Deci, E. L., R. Koestner, R. M. Ryan. 1999. A meta-analytic review of experiments examining the effects of extrinsic rewards on intrinsic motivation. Psych. Bull. 125(6) 627-668.

Dunbar, K. 1995. How scientists really reason: Scientific reasoning in real-world laboratories. R. J. Sternberg, J. E. Davidson, eds. The Nature of Insight. MIT Press, Cambridge, MA, 365-395.

Eisenberger, R., L. Shanock. 2003. Rewards, intrinsic motivation, and creativity: A case study of conceptual and methodological isolation. Creativity Res. J. 15(2-3) 121-130.

Fleming, L., S. Mingo, D. Chen. 2007. Collaborative brokerage, generative creativity, and creative success. Admin. Sci. Quart. 52(3) $443-475$.

Frey, B., A. Stutzer. 2004. Introducing procedural utility: Not only what, but also how matters. J. Institutional Theoretical Econom. 160(3) 377-401.

Frey, B. S., R. Jegen. 2001. Motivation crowding theory. J. Econom. Surveys 15(5) 589-611.

Friedman, R. S., J. Foerster. 2005. Effects of motivational cues on perceptual asymmetry: Implications for creativity and analytical problem solving. J. Personality Soc. Psych. 88(2) 263-275.

Gagne, M., E. L. Deci. 2005. Self-determination theory and work motivation. J. Organ. Behav. 26(4) 331-362.

Gambardella, A., D. Harhoff, B. Verspagen. 2006. The value of patents. Working paper, Bocconi University, Milan.

Giuri, P., M. Mariani, S. Brusoni, G. Crespi, D. Francoz, A. Gambardella, W. Garcia-Fontes, et al. 2007. Inventors and invention processes in Europe: Results from the PatVal-EU survey. Res. Policy 36(8) 1107-1127.

Goldberger, M. L., P. Flattau, B. A. Maher. 1995. Research-Doctorate Programs in the United States: Continuity and Change. National Academy Press, Washington, DC.

Griliches, Z. 1957. Hybrid corn: An exploration in the economics of technological change. Econometrica 25(4) 501-522.

Gundry, L. K. 1993. Fitting into technical organizations-The socialization of newcomer engineers. IEEE Trans. Engrg. Management 40(4) 335-345.

Hackman, J. R., G. R. Oldham. 1976. Motivation through the design of work-Test of a theory. Organ. Behav. Human Performance 16(2) 250-279.

Hamilton, B. H. 2000. Does entrepreneurship pay? An empirical analysis of the returns to self-employment. J. Political Econom. 108(3) 604-631.

Heath, C. 1999. On the social psychology of agency relationships: Lay theories of motivation overemphasize extrinsic incentives. Organ. Behav. Human Decision Processes 78(1) 25-62.

Henderson, R. 1994. The evolution of integrative capability: Innovation in cardiovascular drug discovery. Indust. Corporate Change 3(3) 607-630.

Hennessey, B. A., T. M. Amabile. 1998. Reward, intrinsic motivation, and creativity. Amer. Psych. 53(6) 674-675.

Intellectual Property Owners Association (IPO). 2004. Employee inventor compensation practices survey. IPO, Washington, DC.

Johnson, E. J., J. W. Payne. 1985. Effort and accuracy in choice. Management Sci. 31(4) 395-414.
Jung-Beeman, M., E. M. Bowden, J. Haberman, J. L. Frymiare, S. Arambel-Liui, R. Greenblatt, P. J. Reber, J. Kounios. 2004. Neural activity when people solve verbal problems with insight. PLoS Biology 2(4) 500-510.

Kahneman, D. 1973. Attention and Effort. Prentice-Hall, Englewood Cliffs, NJ.

Katz, R. 2004. Motivating professionals in organizations. R. Katz, ed. The Human Side of Managing Technological Innovation. Oxford University Press, New York, 3-20.

Keller, L. M., T. J. Bouchard Jr., R. D. Arvey, N. L. Segal, R. V. Dawis. 1992. Work values: Genetic and environmental influences. J. Appl. Psych. 77(1) 79-88.

Koenker, R., K. Hallock. 2001. Quantile regression. J. Econom. Perspect. 15(4) 143-156.

Lacetera, N. 2009. Different missions and commitment power in R\&D organizations: Theory and evidence on industryuniversity alliances. Organ. Sci. 20(3) 565-582.

Lacetera, N., L. Zirulia. 2008. Knowledge spillovers, competition, and taste for science in a model of $R \& D$ incentive provision, Working paper, Case Western Reserve University, Cleveland.

Lakhani, K. R., E. von Hippel. 2003. How open source software works: "Free" user-to-user assistance. Res. Policy 32(6) 923-943.

Lazear, E. 1997. Incentives in basic research. J. Labor Econom. 15(1) S167-S197.

Lerner, J., J. Tirole. 2005. The economics of technology sharing: Open source and beyond. J. Econom. Perspect. 19(2) 99-120.

Long, J. S., J. Freese. 2005. Regression Models for Categorical Dependent Variables Using STATA, 2nd ed. Stata Press, College Station, TX.

MacKinnon, D. W. 1962. Intellect and motive in scientific inventors: Implications for supply. R. R. Nelson, ed. The Rate and Direction of Inventive Activity. Princeton University Press, Princeton, NJ, 361-384.

Manners, G., J. A. Steger, T. W. Zimmerer. 1997. Motivating your R\&D staff. Res.-Tech. Management 40(6) 29-34.

Manso, G. 2010. Motivating innovation. Working paper, MIT, Cambridge, MA.

Merton, R. K. 1973. The Sociology of Science: Theoretical and Empirical Investigations. University of Chicago Press, Chicago.

Moorman, R. H., P. M. Podsakoff. 1992. A meta-analytic review and empirical test of the potential confounding effects of social desirability response sets in organizational-behavior research. J. Occupational Organ. Psych. 65(2) 131-149.

Murdock, K. 2002. Intrinsic motivation and optimal incentive contracts. RAND J. Econom. 33(4) 650-671.

Nelson, R. R. 1959. The economics of invention: A survey of the literature. J. Bus. 32(2) 101-127.

Oaxaca, R., M. R. Ransom. 1994. On discrimination and the decomposition of wage differentials. J. Econometrics 61(1) 5-21.

Oi, W. Y., T. L. Idson. 1999. Firm size and wages. O. Ashenfelter, D. Card, eds. Handbook of Labor Economics, Vol. 3B. Elsevier, Amsterdam, 2165-2214.

Ouchi, W. G. 1979. Conceptual-framework for the design of organizational control mechanisms. Management Sci. 25(9) 833-848.

Pedhazur, E. J., L. P. Schmelkin. 1991. Measurement, Design, and Analysis: An Integrated Approach. Lawrence Erlbaum Associates, Hillsdale, NJ.

Pelz, D. C., F. M. Andrews. 1976. Scientists in Organizations: Productive Climates for Research and Development, revised ed. Institute for Social Research, University of Michigan, Ann Arbor.

Podsakoff, P. M., J. Y. MacKenzie, J. Y. Lee. 2003. Common methods bias in behavioral research: A critical review and recommended remedies. J. Appl. Psych. 88(5) 879-903.

Prendergast, C. 1999. The provision of incentives in firms. J. Econom. Literature 37(1) 7-63. 
Roach, M., H. Sauermann. 2010. A taste for science? Ph.D. scientists' academic orientation and self-selection into research careers in industry. Res. Policy 39(3) 422-434.

Roberts, J., I. H. Hann, S. Slaughter. 2006. Understanding the motivations, participation, and performance of open source software developers: A longitudinal study of the Apache projects. Management Sci. 52(7) 984-999.

Rosen, S. 1986. The theory of equalizing differences. O. Ashenfelter, R. Layard, eds. Handbook of Labor Economics. North-Holland, Amsterdam, 641-692.

Ryan, R. M., E. L. Deci. 2000. Intrinsic and extrinsic motivations: Classic definitions and new directions. Contemporary Educational Psych. 25(1) 54-67.

Sauermann, H. 2005. Vocational choice: A decision making perspective. J. Vocational Behav. 66(2) 273-303.

Sauermann, H., P. E. Stephan. 2010. Twins or strangers? Differences and similarities between academic and industrial science. NBER Working Paper 16113, National Bureau of Economic Research, Cambridge, MA.

Sauermann, H., M. Roach, W. Zhang. 2010. Is there a "Taste for Science"? Individuals' preferences and the organization of science. Working paper, Georgia Institute of Technology, Atlanta.

Schmookler, J. 1962. Economic sources of inventive activity. J. Econom. Hist. 22(1) 1-20.

Schumpeter, J. A. 1934. The Theory of Economic Development: An Inquiry Into Profits, Capital, Credit, Interest, and the Business Cycle. Harvard University Press, Cambridge, MA.
Schumpeter, J. A. 1942. Capitalism, Socialism and Democracy. Harper \& Brothers, New York.

Siemsen, E. 2008. The hidden perils of career concerns in R\&D organizations. Management Sci. 54(5) 863-877.

Skinner, B. F. 1953. Science and Human Behavior. Macmillan, New York.

Stephan, P. E. 1996. The economics of science. J. Econom. Literature 34(3) 1199-1235.

Stephan, P. E., S. G. Levin. 1992. Striking the Mother Lode in Science. Oxford University Press, New York.

Stern, S. 2004. Do scientists pay to be scientists? Management Sci. 50(6) 835-853.

Super, D. E. 1964. Work Values Inventory. Houghton-Mifflin, Boston.

Topel, R. 1991. Specific capital, mobility, and wages-Wages rise with job seniority. J. Political Econom. 99(1) 145-176.

Vallas, S. P., D. L. Kleinman. 2008. Contradiction, convergence, and the knowledge economy: The confluence of academic and commercial biotechnology. Socio-Econom. Rev. 6(2) 283-311.

Van Eerde, W., H. Thierry. 1996. Vroom's expectancy models and work-related criteria: A meta-analysis. J. Appl. Psych. 81(5) 575-586.

Weisberg, R. W. 2006. Creativity: Understanding Innovation in Problem Solving, Science, Invention, and the Arts. John Wiley \& Sons, Hoboken, NJ. 